
CEsifo
WORKING

\title{
CEO Compensation: Evidence from the Field
}

Alex Edmans, Tom Gosling, Dirk Jenter 


\section{Impressum:}

CESifo Working Papers

ISSN 2364-1428 (electronic version)

Publisher and distributor: Munich Society for the Promotion of Economic Research - CESifo

$\mathrm{GmbH}$

The international platform of Ludwigs-Maximilians University's Center for Economic Studies and the ifo Institute

Poschingerstr. 5, 81679 Munich, Germany

Telephone +49 (0)89 2180-2740, Telefax+49 (0)89 2180-17845, email office@cesifo.de

Editor: Clemens Fuest

https://www.cesifo.org/en/wp

An electronic version of the paper may be downloaded

- from the SSRN website: www.SSRN.com

- from the RePEc website: $\quad$ www.RePEc.org

- from the CESifo website: https://www.cesifo.org/en/wp 


\title{
CEO Compensation: Evidence from the Field
}

\begin{abstract}
We survey directors and investors on the objectives, constraints, and determinants of CEO pay. $67 \%$ of directors would sacrifice shareholder value to avoid controversy on CEO pay, implying they face significant constraints other than participation and incentive compatibility. These constraints lead to lower pay levels and more one-size-fits-all structures. Shareholders are the main source of constraints, suggesting directors and investors disagree on how to maximize value. Respondents view intrinsic motivation and reputation as stronger motivators than incentive pay. They believe pay matters to CEOs not to finance consumption, but because it affects perceptions of fairness. The need to fairly recognize the CEO's contribution explains why flow pay responds to performance, even though CEOs' equity holdings already provide substantial consumption incentives, and why peer firm pay matters beyond retention concerns. Fairness also matters to investors, with shareholder returns an important reference point. This causes CEO pay to be affected by external risks, in contrast to optimal risk sharing.
\end{abstract}

JEL-Codes: G340, G380, M120, M520.

Keywords: executive compensation, contract theory, CEO incentives, fairness, survey.

\author{
Alex Edmans \\ London Business School, Regent's Park \\ United Kingdom - London NW1 4SA \\ aedmans@london.edu
}

\author{
Tom Gosling \\ London Business School, Regent's Park \\ United Kingdom - London NW1 4SA \\ tgosling@london.edu
}

\begin{abstract}
Dirk Jenter
London School of Economics, Houghton Street

United Kingdom - London WC2A $2 A E$

d.jenter@lse.ac.uk

Current draft: June 30, 2021

We are indebted to the directors and investors who took the time to fill in the survey and, in particular, those who agreed to be interviewed. We are grateful to Vikas Agarwal, Ashwini Aggarwal, Ulf Axelson, Cynthia Baloch, Felipe Cabezon, Joanna Chen, Pierre Chaigneau, Oliver Cover, Vicente Cunat, Naveen Daniel, Ingolf Dittmann, Daniel Ferreira, Xavier Gabaix, Neil Golborne, Juanita Gonzalez-Uribe, John Graham, Moqi Groen-Xu, Cam Harvey, Torsten Jochem, Swami Kalpathy, Robert Macrae, Ernst Maug, Gaizka Ormazabal, Daniel Paravisini, Cameron Peng, Anjana Rajamani, Orkid Russell, Zach Sautner, and seminar participants at Arizona, Colorado, Connecticut, CUHKShenzhen, Delaware, EPFL/Lausanne, Erasmus University Rotterdam, ESSEC, Georgia State, HKUST, LBS, LSE, Lugano, Maryland, NHH, Nottingham, Rutgers, South Carolina, Texas Christian University, Toronto, Tulane, the BI Conference on Corporate Governance, the Drexel Gupta Governance Institute Online Seminar Series, the Florida State University Suntrust Beach Virtual Conference, the Istanbul Finance Seminar Series, and the Minnesota Virtual Corporate Finance Talks for helpful comments. We thank Candice Boclé, Stephen Cahill, Jonathan Dawson, Alan Giles, Steve Golsby, Sandy Pepper, Mike Power, Erica Serpico, and Ben Yeoh for beta-testing the survey, Sai Zhang for outstanding research assistance, and Katty Paredes and especially Janet Chater for coding the questions. We thank the Institute of Directors, Investment Association, Non-Executive Directors Association, and LBS Advancement (Ian Frith and Sarah Jeffs) for their help in survey distribution. We gratefully acknowledge research support from the LBS AQR Asset Management Institute and an LSE STICERD grant.
\end{abstract}




\section{Introduction}

How to design executive pay is a first-order decision for every firm. Pay is critical for attracting, retaining, and motivating a $\mathrm{CEO}$, and affects the wider company beyond the $\mathrm{CEO}$ - high pay may demotivate employees and damage a company's customer reputation. Even more broadly, CEO pay across the economy influences the public's perception of capitalism. As a consequence, CEO pay receives more attention than nearly every other routine corporate decision. Boards have dedicated remuneration committees, investors have a special "say-on-pay" vote, and pay is highly regulated.

Due to its importance, it is critical to understand how CEO pay is set. Academics typically study this question through theorists building models and empiricists testing the models' predictions. While a great deal has been learned through these methods, they have limitations. First, data only documents the outcome of an optimization problem and not the underlying program that led to it. Even if data is consistent with a model, a very different model may have generated it. Second, many key ingredients of compensation models are difficult to measure and thus test.

This paper surveys non-executive directors and institutional investors on how they set or influence pay. Our first goal is to understand the objectives and constraints of contract design, and thus the underlying program. Our second goal is to identify the determinants of pay, by investigating factors that theories deem relevant but are unobservable, or that prior models have overlooked. We distributed the survey in late 2020, receiving responses from 203 non-executive directors of FTSE All-Share companies and 159 investors in UK equities. Most questions allowed respondents to add free-text comments, and we conducted 14 post-survey interviews. The answers reveal several interesting results, organized into four groups:

\section{Objective and constraints}

Our first question asks respondents to rank the importance of three goals when setting CEO pay. $65 \%$ of directors view attracting the right $\mathrm{CEO}$ as most critical, while $34 \%$ prioritize designing a 
structure that motivates the CEO. For investors, these figures are $44 \%$ and $51 \%$ respectively. This reversal reflects a theme that recurs throughout our survey - directors view labor market forces, and thus the participation constraint, as more important than investors, who prioritize the incentive constraint. Only $1 \%$ of directors and $5 \%$ of investors view keeping the level of pay down as their primary goal. This is consistent with CEO pay being a small percentage of firm value, while hiring a subpar CEO or providing suboptimal incentives has potentially large effects.

However, boards feel restricted by far more than the participation and incentive constraints focused on by standard models. $67 \%$ of directors admit that they are willing to sacrifice shareholder value to avoid controversy on CEO pay - from parties such as proxy advisors, employees, and customers. Surprisingly, the strongest constraint is the need to obtain investor support, even though this should be automatic if boards are setting pay optimally. Instead, directors believe that shareholder guidelines, paradoxically, harm shareholder value. 77\% report that such constraints have forced them to offer a lower level of pay, and $72 \%$ an inferior structure.

Most models of CEO pay take the "shareholder value" view that pay is set by a single principal, a shareholder-aligned board. The main alternative is the "rent extraction" view, whereby boards are captured by CEOs and thus do not seek to maximize value. However, our free-text fields and interviews suggest a third perspective - directors and investors share the same objective (shareholder value), but view the world differently. One possibility is that directors better understand the CEO labor market, whereas shareholders push for changes that would violate the CEO's participation constraint or demotivate her ("uninformed investors"). Another is that boards overestimate the value of their CEO or underestimate their latitude to improve pay ("uninformed boards").

To help disentangle these interpretations, we ask the $77 \%$ of directors who were forced to offer lower pay about the consequences. While 7\% report that the CEO left, and $13 \%$ that they hired a less expensive CEO, $41 \%$ admit that there were no adverse effects. This result is meaningful, since any 
self-serving bias would discourage this response. Thus, at least in some cases, boards overestimated the negative consequences of tough decisions on CEO pay. However, $42 \%$ reported that the CEO was less motivated, suggesting that the level of pay affects incentives, in contrast to standard theories.

\section{Incentives and variable pay}

There is greater agreement on the second set of questions - the role of financial incentives in motivating CEOs. Both boards and shareholders believe they are relevant but of secondary importance. The CEO's intrinsic motivation and personal reputation are seen as most important, yet are absent from nearly all theories. Notably, directors view CEOs' career concerns, the focus of a large literature, as third-order: fewer than $20 \%$ view the risk of being fired or a move to a larger firm as an important motivator.

Both boards and investors believe that motivating the $\mathrm{CEO}$ is the main reason for offering variable pay, despite viewing financial incentives as secondary. The free-text responses and interviews suggest that financial incentives reinforce intrinsic and reputational incentives. CEOs believe it is fair to be rewarded financially for good performance; perceived unfairness would erode their intrinsic motivation. As one respondent stressed, "the retrospective acknowledgement of exceptional performance is important." Separately, an increase in realized pay signals the CEO's performance to outsiders, boosting her reputation.

These responses suggest that incentive pay may work through different channels to standard models. In these models, the CEO only improves firm value if her utility from consuming the resulting pay increment exceeds the effort required to do so - the contract offers sufficient consumption incentives. Our respondents instead suggest that variable pay provides ex-post recognition. A CEO does not need the extra pay to finance consumption, but believes it is fair to be recognized for a job well done. 
The importance of ex-post recognition has two implications. First, it suggests that a CEO assesses her pay not only for the consumption utility it provides, but also against her expectation of a fair reward. This expectation is believed to be affected by at least two reference points - the CEO's contribution to the company and the pay of her peers.

Second, flow pay plays a special role not provided by portfolio incentives. In standard theories, only total incentives matter - it is irrelevant whether they stem from changes in flow pay or the value of existing equity. Fairness models are similarly silent about where a fair reward should come from. Empirically, incentives from existing equity are much greater, so standard measures of CEO incentives ignore flow pay. However, changes in flow pay provide greater ex-post recognition, because they require a discretionary decision by the board and are voted on by shareholders. They are also publicly disclosed, boosting the CEO's reputation. Thus, they may be important even if the CEO holds significant equity.

Two other reasons for variable pay are strongly supported by both directors and investors: attracting or retaining a high-ability or hard-working $\mathrm{CEO}$, and for the $\mathrm{CEO}$ to share external risks with investors and stakeholders. The second reason is surprising and contradicts standard theories, since it implies inefficient risk-sharing. It is, however, consistent with a fairness model in which directors and investors also evaluate CEO pay relative to a set of reference points that includes shareholder returns.

When asked about the split between fixed and variable pay, neither directors nor investors assign much relevance to CEO risk aversion and firm risk, the split's main determinants in standard models. This indicates a wide gulf between the models and real-world practice.

Pay levels

Our third set of results concerns the level of pay. We first ask what determines the pay of a new CEO. Both directors and investors view CEO ability as most important. Unexpectedly, pay at peer 
firms is seen as more important than the new CEO's actual outside options, such as pay at her prior firm and at other firms she could move to. One explanation, supported by the free-text fields and interviews, is that peer compensation matters not only because it determines the CEO's alternatives, but because it is a reference point she uses to assess whether her pay is fair.

When asked about increases in expected pay for incumbent CEOs, both directors and investors state that the primary justification is good recent performance. This is surprising given the substantial equity holdings that CEOs have, but is consistent with changes in flow pay providing ex-post recognition. Other justifications receive only minor support.

Directors also report that decreases in expected pay are rare, with $77 \%$ never having implemented one. Interestingly, while directors believe that good recent performance justifies pay increases, they do not believe that poor performance justifies decreases. Several interviewees explained that pay cuts would demotivate the CEO and, if performance were poor enough to warrant a cut, they would fire her instead. The two justifications for pay decreases with the most support are external pressure and financial constraints, likely because they are less detrimental to the CEO's sense of worth.

\section{"Suboptimal" pay practices}

Finally, we study the reasons for apparently suboptimal pay practices. The first is the limited use of relative performance evaluation. Directors support three explanations, absent from existing theories, for why they do not filter out industry conditions from all performance measures. One is again fairness - CEOs should benefit from an upswing since investors and stakeholders do. ${ }^{1}$ The other two reasons are practical - it can be difficult to find suitable peers for some firms, or to observe peer performance for some performance measures. Explanations proposed by existing models, such as keeping pay competitive with peers during upswings, receive little support.

\footnotetext{
${ }^{1}$ Even if investors are benchmarked, the benchmark is often a market rather than an industry index, so they benefit from industry upswings.
} 
A second apparently suboptimal practice is the short-term nature of many pay incentives. Here, directors' and investors' views differ sharply. 78\% of investors believe the CEO would make better decisions if incentives were more long-term. Fewer than $6 \%$ agree with each of three potential concerns - that long-term incentives are less effective motivators, would jeopardize CEO retention or recruitment, or would require a costly adjustment in pay level. In contrast, directors view incentives as already sufficiently long-term, and only $21 \%$ believe that further lengthening would improve decisions. Instead, they view all three concerns as important.

\section{Contribution to the literature}

This paper builds on the literature on CEO compensation, recently reviewed by Murphy (2013), Edmans and Gabaix (2016), and Edmans, Gabaix, and Jenter (2017). It is also related to other corporate finance surveys, such as Graham and Harvey (2001), Graham, Harvey, and Rajgopal (2005), Brav et al. (2005), Ben-David, Graham, and Harvey (2013), and Graham, Harvey, and Puri (2013). A unique feature is that we survey both directors and investors, allowing us to investigate how their views differ. The above papers study executives only; others study investors only, such as McCahery, Sautner, and Starks (2016), Krueger, Sautner, and Starks (2020), and Gompers et al. (2020). CEO pay is arguably the decision on which investors have the greatest influence, given their say-on-pay votes, and thus an interesting setting to compare their views with directors.

This paper proceeds as follows. Section 2 discusses the motivation for our survey and introduces a simple model to frame our tests. Section 3 describes how we conducted the survey and aimed to address the methodology's limitations, and the context of UK executive pay. Section 4 presents the results on the objectives and constraints of CEO pay design, Section 5 addresses the level of pay, and Section 6 its structure. Section 7 explores who sets CEO pay in practice and Section 8 concludes. 


\section{Motivation: Standard Theory vs. Real-World Practice}

A key goal of the survey is to guide future compensation theories. Many assumptions have become sufficiently standard that they do not need to be explicitly stated. To illustrate these assumptions and the value in scrutinizing them, and provide a framework to motivate some of our survey questions, we briefly review the classic model of Holmstrom and Milgrom (1987, "HM”). Its key assumptions are inherent in almost all shareholder value theories, but we choose this one as it is particularly tractable.

The principal (board acting on behalf of shareholders) hires an agent (CEO). Firm value is given by $V=b a+\varepsilon$ where $a \in[0, \infty)$ is an action ("effort") taken by the CEO. $b$ parametrizes the productivity of effort and $\varepsilon \sim N\left(0, \sigma^{2}\right)$ is normally distributed noise. The CEO's utility function is given by $u(c, a)=$ $-\exp (-\eta(c-g(a))$, where $c$ is consumption, $\eta$ is absolute risk aversion, and $g(a)$ is the cost of effort. The CEO has a reservation consumption level of $\underline{c} \geq 0$, and HM assume a quadratic cost, $g(a)=1 / 2 g a^{2}$. The firm pays the CEO a wage $w$, which she fully consumes. Thus, to simplify notation, we use $c$ to denote both the firm's payment and the CEO's consumption in this section.

The principal chooses a contract $c(V)$ and an effort level $a$ to solve:

$$
\begin{aligned}
& \operatorname{Max} E[V-c] \\
& \text { s.t. } E\left[-\exp \left(-\eta\left(c-1 / 2 g a^{2}\right)\right] \geq-\exp (-\eta \underline{c})\right. \\
& a \in \operatorname{argmax}_{a^{\prime}} E\left[-\exp \left(-\eta\left(c-1 / 2 g a^{\prime 2}\right)\right]\right.
\end{aligned}
$$

(1) is the objective function: expected firm value net of CEO pay. (2) is the participation or individual rationality ("IR") constraint, which ensures that the CEO is paid at least her outside option. (3) is the incentive compatibility ("IC") constraint, which ensures that the CEO exerts effort $a$. Under 
the optimal contract, both the IR and IC will bind. HM show that the optimal contract is linear in firm value, i.e. $c=\varphi+\theta V$, where incentives $\theta$ and fixed salary $\varphi$ are respectively given by:

$$
\begin{aligned}
& \theta=\left(1 /\left(1+g \eta \sigma^{2} / b^{2}\right)\right) \\
& \varphi=\underline{c}-1 / 2 \theta^{2} b^{2} / g+(\eta / 2) \theta^{2} \sigma^{2} .
\end{aligned}
$$

Incentives $\theta$ are determined by a trade-off. When the benefit of effort $b$ is higher and the $\operatorname{cost}$ of effort $g$ is lower, it is optimal to induce more effort, so incentives are stronger. When the CEO's risk aversion $\eta$ and firm risk $\sigma^{2}$ are higher, incentives impose more risk on the CEO, so they are optimally lower. The fixed salary $\varphi$ is chosen to keep the CEO at her reservation utility.

Models such as HM deliver predictions for the determinants of pay and incentives, and thus have been extensively tested. For example, a single implication - that risk $\sigma$ reduces incentives $\theta$ - has been studied by a large number of papers with mixed results. ${ }^{2}$ Given the substantial empirical work that theories have spawned, and the mixed evidence, it is important to scrutinize whether their assumptions describe reality.

Starting with the objective function, (1) assumes that the only downside of high CEO pay is that it directly reduces shareholder value. However, it may also demotivate employees or harm the firm's customer reputation. Moreover, the board's objective function may not be shareholder value, but, for example, to avoid losing a say-on-pay vote. Turning to the participation constraint (2), it is not clear that it binds in practice, given the magnitude of CEO salaries. The incentive constraint (3) also may not bind, if intrinsic motivation or reputational concerns are sufficient to motivate the CEO. The CEO's preferences, reflected in (2) and (3), may be richer than a simple function of effort and

\footnotetext{
${ }^{2}$ Section 2.3.2 of the survey by Edmans, Gabaix, and Jenter (2017) lists several papers that find a positive relationship, several that document a negative relationship, and several that show no relationship or mixed results.
} 
consumption. Real-world CEOs likely also care about their reputation, fairness, and being appreciated by directors and investors.

Considering the entire program (1)-(3), it ignores many other potential constraints. Boards and CEOs do not negotiate pay in a vacuum. Norms on what investors and stakeholders deem acceptable may limit the level of pay or prevent its structure from deviating substantially from peer practices.

\section{Method and Context}

\subsection{Surveys Versus Archival Research}

The standard empirical methodology is archival research. This has several advantages, such as large datasets, objectivity, and the ability to control for multiple factors. However, it also has limitations. For example, it is difficult to measure key theoretical determinants of CEO pay, such as the cost of effort $g$, benefit of effort $b$, and risk aversion $\eta$. Even if an empirical proxy can be found, a statistical relationship could have multiple interpretations. A finding that CEO pay is sensitive to performance could be because variable pay is used to incentivize effort, to screen out low-ability CEOs, or to ensure the CEO shares risks with investors and stakeholders. While archival research studies what drives pay, it is less able to investigate why these factors drive pay.

The survey methodology itself has limitations, and we have endeavored to design the survey to attenuate, if not eliminate, them. First, respondents may interpret the questions differently to how we envisaged. We engaged in extensive beta-testing of the survey and provide free-text fields after each question to establish whether there were persistent misinterpretations. A second is the Friedman (1953) "as if" critique, that contract designers may act in accordance with a theory but be unable to articulate it. Conversely, they may give a high score to a response because it sounds logical. We reduce this risk by not explaining the rationale behind a response. For example, when exploring the determinants of incentives $\theta$, we ask about the importance of "how risky the firm is" rather than "the 
riskier the firm is, the weaker incentives are as they expose the CEO to too much risk." While the latter explanation might identify the mechanism more precisely, a respondent might score this option highly because the explanation seems sensible.

Third, respondents may misreport their answers. In addition to guaranteeing anonymity, we tried not to ask questions that would likely lead to misreporting. For example, we did not ask directors why pay is so high, as this may prompt rationalizations even if pay were unjustified, but instead asked what would happen if pay were lower. Finally, our questions may be limited by the "academic paradigm", i.e., restricted to what academic literature suggests is relevant. We addressed this concern by having a practitioner coauthor, beta-testing the survey to see if we had omitted important factors, and including free-text fields. If the free-text fields systematically suggested a response outside our set of options, we explored it in interviews.

\subsection{The UK Context}

We study executive pay in the UK for a number of reasons. The UK was the first country to adopt say-on-pay, introducing legislation in 2002. Therefore, UK investors have significant experience in evaluating, voting on, and engaging on CEO pay. We believe that most of our conclusions will generalize to other countries. Say-on-pay has become widespread throughout the world, with the EU Shareholder Rights Directive imposing a similar regime to the UK. In both the US and Europe, major investors are setting expectations on pay and voting in an increasingly consistent manner, and many of those attitudes (e.g., on relative performance evaluation) were formed in the UK. In addition, there has been growing convergence in both pay levels and structures around the world (Fernandes et al., 2013); while discrepancies remain, the UK lies between the US and Europe in both the level and structure of pay, rather than being an outlier. ${ }^{1}$

A UK company must establish a Remuneration Committee (RemCo) of independent directors to set the pay of executive directors. The RemCo is required to hold two say-on-pay votes. At least every 
three years, it puts its remuneration policy to a binding "policy vote." This sets the framework within which the RemCo must make pay decisions; any deviation is illegal. Every year, the decisions the RemCo makes within the policy are put to a non-binding "implementation vote."

Beyond say-on-pay, boards are also constrained by the 2018 revision of the UK Corporate Governance Code (the "Code") and investor guidelines; violations can lead to significant voting opposition. For example, the revised Code requires the pension contributions of executive directors to be aligned with the wider workforce. In 2018, CEO pensions had contribution rates of up to $50 \%$ of salary, while employee schemes were below $10 \%$, so the Code led to large reductions for CEOs. Firms are required to disclose total realized pay, known as the "single figure." This includes salary, annual bonus, and cash and equity earned ${ }^{3}$ as part of "long-term incentive plans" (LTIPs).

The survey was carried out in the context of the COVID-19 pandemic, in which many firms reduced CEO pay either due to concerns about fairness with the wider workforce or financial difficulties. This allows us to study the causes of pay reductions, which are typically rare. Online Appendix B provides additional contextual information plus stylized facts on UK CEO pay.

\subsection{Survey Design and Delivery}

We benefited from extensive feedback on our questions before launching the survey. We obtained feedback from academics by presenting the questions at conferences and seminars, and sending them to leading researchers. We sent several drafts to the UK government's department of Business, Energy, and Industrial Strategy, which has significant experience in administering surveys to guide government policy. We beta-tested the survey with directors, investors, and compensation consultants to ensure that they were interpreting the questions as we intended, check the survey was not too long

\footnotetext{
${ }^{3}$ This is based on when performance conditions are tested. The equity earned may not yet be paid out, since there may be additional holding periods. New grants of equity are disclosed separately from the "single figure," together with the performance conditions that govern their vesting.
} 
(our target was 15 minutes), and explore if we were missing key dimensions. Most of these beta tests occurred via Zoom, where the practitioners answered the questions "aloud," so we could see how they were interpreting them.

We launched the survey in November and December 2020. To encourage responses, we donated $£ 100$ for each completed survey (up to a total of $£ 25,000$ ) to the UK's National Health Service COVID appeal, and offered respondents the option to receive a draft of the working paper before its public release. ${ }^{4}$ We administered the survey using the Qualtrics online platform, offering respondents a generic (rather than individualized) link to guarantee their anonymity. Except for the demographic questions, we randomized the order of responses within each question.

We surveyed two types of respondent. The first was non-executive directors of FTSE All-Share companies (excluding investment trusts), which we identified from CapitalIQ and BoardEx; we attempted to contact every director. The second was investors in UK equities. There are two relevant types: asset managers and asset owners (such as pension funds). Some asset owners vote directly on CEO pay; others give asset managers guidance on how they should vote. ${ }^{5}$ Within an asset manager/owner, there are both fund managers and governance specialists (otherwise known as "stewardship" or "responsible investment" specialists). The latter coordinate voting and engagement across the asset manager/owner's funds.

We attempted to contact every fund manager of all UK equity funds listed on Trustnet, a wellknown database of funds offered in the UK, as well as every Head of Responsible Investment of all

\footnotetext{
${ }^{4}$ To opt in to receive the draft, after completing the survey, participants were invited to add their email address. This final step was optional; approximately half the respondents filled it in. Many respondents were not identifiable from their email. ${ }^{5}$ Institutional asset owners in the UK are required to have a policy on governance and engagement. Many of these make reference to CEO pay. The Association of Member Nominated Trustees is a professional body for pension fund trustees which has a set of "red line" voting principles, including on CEO pay. Pension funds can choose which principles they would like asset managers to adopt; doing so means that, if the red line is crossed, they expect the asset manager to vote against. Other asset owners work with a proxy advisor to develop a custom voting policy that is applied on their behalf.
} 
signatories to the UK Stewardship $\operatorname{Code}^{6}$ and members of the UK Sustainable Investment and Finance Association. For some, the main contact for responsible investing was a Chief Investment Officer ("CIO"), fund manager, or stock analyst. Online Appendix A provides further details on our distribution procedure.

In total, we contacted 1,312 non-executive directors of 421 firms and 556 investors at 231 asset managers or asset owners. We obtained responses from 203 directors and 159 investors; 170 (132) answered every question. This corresponds to a response rate of $15.5 \%$ for directors $(13.0 \%$ counting only directors who answered every question) and $28.6 \%(23.7 \%)$ for investors. This compares favorably with response rates of $4-15 \%$ reported in the survey papers referenced in Section 1 . The results presented are based on all responses, but do not change materially if we only include respondents who answered every question. After receiving the survey results, we interviewed 14 respondents to explore the reasons behind their responses. The interviewees were a mix of investors and directors across industries; the investors included both asset managers and asset owners, and both fund managers and governance specialists.

Table 1 presents summary statistics on the director respondents. Panel A shows that 39\% were from the FTSE 100, 36\% from the FTSE 250 (the next 250 largest firms), and 22\% from the FTSE Small Cap index. Panel B shows a broad industry representation, with financial services being the most common, consistent with the composition of the UK stock market. Panel C shows that $27 \%$ of respondents were board chairs, 33\% were RemCo chairs, and 24\% were RemCo members. Panel D shows the distribution of the size of the largest shareholder. Interestingly, director responses varied little with firm size or whether the firm had a large blockholder.

\footnotetext{
${ }^{6}$ Asset manager and asset owners who sign up to the voluntary UK Stewardship Code pledge to exert governance on their investee companies.
} 
Table 2 contains summary statistics for the investor respondents. Panel A shows that $80 \%$ were from asset managers, $8 \%$ from asset owners, and 13\% from hybrid asset manager/owners such as pension funds. Panel B shows that $52 \%$ of respondents were governance specialists, $26 \%$ fund managers, 8\% stock analysts, and 6\% CIOs. Fund managers, stock analysts, and CIOs are primarily evaluated according to investment returns, and thus may be more concerned with the impact of pay on firm performance. (Where there is no confusion, we will use "fund managers" to encompass these three categories). Governance specialists may be more sensitive to the societal consequences of pay. However, the responses from fund managers and governance specialists were generally similar, and we will highlight the few cases in which they differed. Panel C shows that $61 \%$ of investors described their investment style as "wholly active" and 28\% as "mainly active." Only 5\% identified as working for "wholly index" or "mainly index" funds, consistent with index funds being dominated by a small number of providers. Panel D shows the size distribution by assets under management. Results were generally similar across large and small managers and owners.

\section{The Objectives and Constraints of CEO Pay Design}

\subsection{Objectives}

Our first set of questions aims to study directors' and investors' objectives and the constraints they are operating under. The program in Section 2 involves three stages, assuming a given effort level: (1) minimizing the level of pay subject to (2) the structure inducing the required effort level (i.e. the IC being satisfied) and (3) the CEO accepting the contract (i.e. the IR being satisfied). Accordingly, our first question (Q1) asks respondents to rank these three elements ("Rank the importance of the following goals when setting CEO pay").

Table 3 illustrates the results. Both directors and investors view minimizing the level of pay ("keep the quantum of pay down") as least important, with $91 \%$ of directors and $85 \%$ of investors 
ranking it last. ${ }^{7}$ This result is consistent with CEO pay being a small percentage of firm value for most firms. It is also consistent with "shareholder value" models where the CEO's talent (Gabaix and Landier, 2008) and effort (Edmans and Gabaix, 2011) have multiplicative effects on firm value, making it worthwhile to pay the level required to attract and incentivize a talented CEO.

In contrast, $65 \%$ of directors and $44 \%$ of investors view hiring and retention ("attract/retain the right CEO") as most important, while 34\% of directors and 51\% of investors rank the structure of pay ("design a structure that motivates the CEO") most highly. This reversal is a theme that recurs throughout the survey - directors perceive labor market forces, and thus the participation constraint, as crucial, while investors assign greater importance to the incentive constraint.

There are two potential reasons for this divergence. The first is that directors and shareholders have different objectives. One possibility is that shareholders wish to maximize shareholder value but the board is captured by the CEO, or does not wish to exert effort to restructure pay or recruit a new $\mathrm{CEO}$ - and cites competitive pressures as an excuse. The board may also not maximize shareholder value because it is undiversified and thus concerned with idiosyncratic risk. As a result, it may not push for a contract that improves shareholder value in expectation but risks leading to a CEO departure. We use "weak boards" to capture all these reasons. A second possibility is that shareholders do not wish to maximize shareholder value. Asset managers may maximize fund flows, which requires reflecting client concerns about CEO pay even if non-value-maximizing. ${ }^{8}$ Alternatively, investors may maximize value across their portfolio and thus take externalities into account - for example, lowering pay at one firm may make it easier to lower pay at others.

The second explanation is that both boards and investors have the same objective - shareholder value - but disagree on how to maximize it. This disagreement may stem from two sources. One is

\footnotetext{
7 "Quantum" is the term most commonly used by UK practitioners for the target level of pay, i.e., expected pay.

${ }^{8}$ See Dasgupta, Fos, and Sautner (2021) for a survey of the literature on flow-concerned asset managers.
} 
"uninformed investors." Investors underestimate labor market pressures, the difficulty of the CEO job, or the value created by a CEO. Boards better understand these issues, particularly since most directors have executive experience. Several free text responses from directors supported this view. One noted: "Good people are leaving the plc [public limited company] world for private equity in droves. Fund management companies should not throw stones." Even if the participation constraint is slack, investors may be unaware that reducing pay may demotivate the CEO by making her feel unfairly treated. Potentially suggestive of uninformed investors, particularly governance specialists, this is one of the few questions to which fund managers and governance specialists responded differently. $64 \%$ of fund managers ranked "attract/retain the right CEO" and 36\% "design a structure that motivates the CEO" as most important - almost exactly matching the result for directors.

The other potential source of disagreement is "uninformed boards" - directors may underestimate their latitude to restructure pay, or the depth of the $\mathrm{CEO}$ labor market in case a restructuring causes the CEO to leave. Later responses show that investors believe many boards to be weak or uninformed.

\subsection{Constraints}

Our next set of questions studies whether directors and investors perceive constraints over and above the IR and IC considered by standard theories. Q2 asked directors "How large a sacrifice in shareholder value would you make to avoid controversy on CEO pay?", and investors the analogous question "how large a sacrifice in shareholder value would you tolerate firms making to avoid controversy on CEO pay?" (For brevity, for future questions we will include the analogous wording for investors in only the results table, not the main text).

Notably, $67 \%$ of directors would sacrifice shareholder value to avoid controversy, and $56 \%$ of investors would tolerate directors doing so (Table 4, Panel A). This suggests that boards and investors feel restricted by far more than the IR and IC. For example, they may be concerned about their own 
reputation - a controversial pay package could lead to public criticism of directors or investors' clients withdrawing funds.

We next asked about the sources of controversy and the consequences of avoiding it. To the respondents who would tolerate a sacrifice, we asked Q2b, "How important is it to avoid controversy with the following parties?" This question, and the majority of our remaining questions, is scored according to a Likert scale with -2 representing "not at all important", 2 representing "very important", and 0 being neutral. ${ }^{9}$ We will often report results in the form " $\mathrm{x} \% / \mathrm{y}$ ", where $\mathrm{x}$ is the percentage of respondents who selected 1 or 2 , i.e. important or very important, and $y$ is the average rating. For some future questions, -2 represents "strongly disagree" and 2 represents "strongly agree"; the scale for each question is shown in the relevant table. For brevity, we will use "important" to refer to "important or very important", "agree" to refer to "agree or strongly agree", and so on. Also to avoid cumbersome prose, we will sometimes say "our results suggest that x" rather than "our results suggest that directors and investors believe that x"; however, it is important to bear in mind throughout that our survey only reports directors' and investors' perceptions.

Table 4, Panel B shows that $88 \%$ of directors view it as important to avoid controversy with investors; this response also received by far the highest average rating (1.24). This result is surprising. With symmetric information and objectives, controversy with investors would be avoided by maximizing, not sacrificing, shareholder value. Instead, paradoxically, directors believe they have to sacrifice shareholder value to satisfy shareholder requirements. One director wrote that "shareholders appoint RemCos and then often seek to micromanage their duties."

Directors rated employees as the second most important source of controversy $(63 \% / 0.69)$, consistent with concerns about internal equity that we will revisit later. The third highest was proxy advisors (48\%/0.45), consistent with research showing that they significantly affect say-on-pay

\footnotetext{
${ }^{9}$ The original survey labelled the options 1 to 5 , but we have rescaled them from -2 to 2 so that 0 is the neutral score.
} 
outcomes (Malenko and Shen, 2016) with negative shareholder value consequences (Larcker, McCall, and Ormazabal, 2015). Like the "investors" result, this high score is interesting, as proxy advisors should be acting in shareholders' interest. Instead, they may not be maximizing shareholder value, perhaps because they impose one-size-fits-all rules (Iliev and Lowry, 2015; Cabezon, 2020; Jochem, Ormazabal, and Rajamani, 2021). Shareholders, on the other hand, believe the main sources of controversy to be employees $(82 \% / 1.26)$, customers $(75 \% / 1.14)$ and policymakers $(65 \% / 0.92) .{ }^{10}$ $44 \%$ of shareholders rated "other investors" as an important source of controversy, suggesting they believe that other investors cause boards to depart from value maximization.

\subsection{Constraints and the Level of Pay}

We next drill down into the consequences of the constraints from avoiding controversy, focusing on the level in this subsection and the structure of pay in the next. Because these questions are about the actual CEO pay contracts offered, we asked them to directors only.

Q12a ("Have any of the following ever caused you to offer a lower quantum of CEO pay than you would like?") studies whether constraints affect the level of pay. In addition to external constraints, we also include two internal ones. The first is "restrictions from our existing approved pay policy," given investors' binding policy vote. The second is "unwillingness to deviate substantially from how we have paid in the past," given the potential influence of history.

$77 \%$ of directors report that at least one of these non-standard constraints has forced them to offer lower pay than they would like (Table 5, Panel A). 60\% offered less pay to avoid the "risk of investor opposition," and 53\% to avoid the "risk of "vote against' recommendation from a proxy advisor." A

\footnotetext{
${ }^{10}$ Most investors do not perceive proxy advisors $(30 \% /-0.12)$ as reducing value, likely because they view their recommendations as informative, and/or believe they know when to deviate if they are uninformative (see Iliev and Lowry (2015) for consistent evidence).
} 
minority feel constrained by the existing pay policy $(44 \%)$, the need to avoid controversy with employees, the media, customers, or policymakers $(37 \%)$, or past pay practices $(28 \%)$.

To the $77 \%$ of directors who answered "Yes" to at least one constraint, Q12b asked "Did this lower quantum ever lead to the following consequences?" In many "shareholder value" models, CEOs are at their participation constraint, so the only possible outcomes are that the current CEO leaves or the firm hires a different CEO. However, only $7 \%$ report that the CEO left, and $13 \%$ that they hired a less expensive CEO.

By far the most popular responses are not predicted by standard theories. $42 \%$ of directors reported that "the CEO was less motivated." In standard models, motivation depends only on the sensitivity $\theta$, and not the level of pay $\varphi$. Instead, this response is consistent with the "gift exchange" efficiency wage model of Akerlof (1982) - if a CEO is given a gift of fair pay, she will reciprocate by providing discretionary effort. Alternatively, in line with the free text entries and the responses to later questions, it is also consistent with Hertzberg's (1959) view that fair pay is a "hygiene factor" that demotivates if not provided. ${ }^{11}$

Thus, pay may matter per se, not just for the extra consumption that it can buy. When the CEO chooses whether to work, she might not calculate the marginal disutility of effort $\left(g^{\prime}(a)\right)$ and compare it to the marginal increase in consumption utility $\left(u^{\prime}(c)\right)$ from increasing effort (or act "as if" she solved this optimization). Instead, she compares her pay $c$ to what she believes is fair; if she is paid unfairly, she may be demotivated and reduce effort. As one director said about the consequences of a lower quantum of pay, "[the CEO] still did the job, but his morale was affected negatively." Another wrote: "There is first a test of pay fairness by the CEO, then after that, it is about building reputation" - reputational concerns incentivize CEOs to perform, but only if they first believe their pay to be fair.

\footnotetext{
${ }^{11}$ Hertzberg's two-factor (or motivation-hygiene) theory proposes that employees have higher-order psychological needs ("motivators"), such as achievement, recognition, and responsibility, which cause job satisfaction, and lower-order needs ("hygiene factors"), such as fair pay and comfortable conditions, which cause dissatisfaction and demotivate if not given.
} 
Formally, the CEO's utility function may be of the form $U(w-f(\boldsymbol{X}))$, where $w$ is the CEO's wage, $\boldsymbol{X}$ is a vector of reference points that determine what she believes to be fair, and $U($.$) exhibits a$ discontinuity at zero. One potential functional form for $f$ is $\max \left(x_{1}, x_{2} \ldots\right)$ in which case the CEO's pay must exceed all reference points, else she perceives it as unfair. The dependence on $w$ (rather than c) highlights how the CEO's utility depends on the wage per se, rather than the consumption utility it provides. Future questions will shed light on what these reference points might be.

The second-most reported effect of lower pay was "there were no adverse consequences" (41\%). This high frequency is meaningful - response bias would work against directors admitting that external pressures led to them taking a value-creating action that they would not have done otherwise. Thus, in many cases, directors had greater latitude to cut pay than they thought, consistent with weak or uninformed boards. For example, even if the CEO is unhappy about lower pay, intrinsic motivation or reputation may ensure she remains incentivized.

There are two caveats to this interpretation. One is that some reductions in CEO pay were caused by the COVD-19 pandemic or by coordinated pressure on executive pensions (see Section 3.2), which reduced pay across the market. Reducing pay in isolation may have led to adverse consequences. A second is that uncertainty may have made boards' unwillingness to cut pay ex ante optimal due to a high $(100 \%-41 \%=59 \%)$ likelihood of negative effects. This is particularly the case if retaining and motivating the right $\mathrm{CEO}$ are more important than the level of pay, as reported in Table 3.

\subsection{Constraints and the Structure of Pay}

We next investigate how these non-standard constraints affect the structure of pay. Q13a asked "Have any of the following ever caused you to offer an inferior structure of CEO pay to what you would like?" Table 6, Panel A presents the results. Similar to Q12a on pay levels, boards perceive binding constraints. $72 \%$ of directors report that they were forced to offer an inferior pay structure, mostly because of proxy advisors (54\%) or investors (54\%). Restrictions from the approved pay 
policy (40\%), risk of controversy with other parties $(29 \%)$, and pay history $(16 \%)$ also received similar response rates to Q12a. We offered two additional options specific to the structure of pay. One is restrictions from regulation or governance codes $(36 \%)$, since the Code requires executives to hold equity for at least five years and be subject to clawbacks. The second is "adverse tax, accounting, or disclosure implications" (10\%). Murphy (2013) argues that these factors influence pay structures in the US, but UK directors do not view them as important, likely because UK rules are generally applied consistently across all forms of pay.

To the $72 \%$ of respondents who selected "Yes" to at least one constraint, we ask Q13b, "Was the structure inferior in the following ways?" Table 6 , Panel B shows that $69 \%$ reported that they had to "follow market practice more," likely to comply with one-size-fits-all rules applied by investors or proxy advisors. For example, one director said that his board "could have used more creative nonstandard vehicles but didn't." This result echoes Cabezon (2020), who shows that US pay packages have become more homogenized in recent years.

The second most common consequence was offering less upside for good performance (65\%). This is interesting since investors, the main source of constraints, view motivating the CEO as important (Table 3). One interpretation is that investors believe that too much upside has perverse consequences. A second is that investors are concerned that the media or customers may object to pay above a certain level, even if justified by performance.

$57 \%$ of directors were forced to use more performance conditions, perhaps because investors and stakeholders demand that pay be linked to particular measures. One director reported that "complexity is undermining rem packages but to balance all the stakeholders it creeps in." An interviewee complained that different investors have different objectives and each asks for a performance condition to reflect theirs. 
In free-text entries and interviews, several directors and investors explained that they would prefer to pay CEOs like owners, providing large equity stakes, small annual bonuses, and no LTIPs. This would entail unlimited upside for good performance and no performance conditions, violating some of the above constraints. One director, when interviewed, pointed out that large equity stakes are used successfully within private firms. However, when a company goes public, it immediately gets benchmarked against other public firms, and thus has to offer the model of bonuses and (capped) LTIPs "because this is what everyone else does." Another wrote that "we have held off changing from LTIPs to share award schemes for some of the above reasons." Several investors stated that they would like CEOs to be paid in restricted shares to achieve maximum alignment, but that other investors or proxy advisors would object because such a scheme does not fit their standard models.

\subsection{Summary}

Our questions on the objectives and constraints of pay yield the following conclusions:

1. Directors view attracting and retaining the CEO (satisfying the IR) as the most important goal of pay, while investors believe that motivating the CEO (satisfying the IC) is more important. Both view reducing the level of pay as least important.

2. Boards feel constrained by far more than just the IR and IC. $67 \%$ of directors would sacrifice shareholder value to avoid controversy on CEO pay, and $56 \%$ of investors would tolerate directors doing so.

3. Directors view avoiding controversy with investors as the main constraint, suggesting that boards and shareholders disagree on the contract that maximizes shareholder value. Directors also view proxy advisors as a significant constraint; both directors and especially investors view avoiding controversy with employees as important.

4. These additional constraints matter. $77 \%$ of directors reported that constraints forced them to offer a lower level of pay. $41 \%$ of directors admitted that doing so had no adverse 
consequences, while $42 \%$ stated that it reduced the CEO's motivation. The latter is inconsistent with many contracting models, but is consistent with pay being a hygiene factor and unfair pay being a demotivator.

5. $72 \%$ of directors report that constraints forced them to offer an inferior pay structure. This typically involved less tailoring and reduced upside for good performance.

\section{The Level of Pay}

This section studies the determinants of the level of pay. We investigate the pay of a new CEO upon appointment (Section 5.1) separately from subsequent increases (Section 5.2) and decreases (Section 5.3). Section 5.4 analyzes whether boards and investors believe the level of pay can be cut.

\subsection{Pay of a New CEO}

Q3 asks: "How important are the following factors in determining the target quantum of pay for a new CEO?", and aims to capture the determinants of the ex-ante expected value $E[c] .{ }^{12}$ The results are in Table 7. "The new CEO's ability" is the most popular response for both directors $(85 \% / 1.29)$ and investors (90\%/1.49), consistent with talent-based models such as Gabaix and Landier (2008) and Terviö (2008). Perhaps less expected are the high responses to "how attractive our firm is to run (e.g. prestige, risk, complexity)". ${ }^{13}$ Many critics of high pay believe that the CEO job involves little disutility, or that any differences in disutility between firms are negligible compared to the typical CEO salary, so it should not be a significant driver of pay. In contrast, this response was the second

\footnotetext{
${ }^{12}$ In the academic literature, the level of pay refers to the ex-ante expected value $E[c]$, but this concept is not easy to translate into practitioner terminology. In beta-testing, the "level" of pay was interpreted as realized pay, in which case it is mechanically linked to factors such as CEO ability, as a high-ability CEO will hit bonus thresholds. "Expected pay" was interpreted as the amount of pay that the CEO expects to receive, i.e., believes she deserves. The beta-testing revealed that "target quantum" best captured $E[c]$. In addition, at the start of the "Level of Pay" section, we stated "In this survey, the quantum of pay should be taken to refer to the target level of total remuneration set by the remuneration committee." ${ }^{13}$ Prestige and complexity aim to capture both the non-pay benefits and difficulties, i.e., the net disutility, of the CEO's job. Both free-text fields and interviews only referred to prestige and complexity, not risk. This is consistent with the empirical finding of Albuquerque, Albuquerque, Carter, and Dong (2020) that risk has little effect on the level of pay.
} 
most popular option for investors $(61 \% / 0.61)$ and third for directors $(68 \% / 0.76)$. In several free-text fields and interviews, directors stressed how difficult the CEO job is - involving extremely long hours, being constantly in the media, and facing pressures not faced by other executives (such as having to waive bonuses during COVID).

"CEO pay at peer firms" was the second most popular response for directors $(66 \% / 0.82)$ and third highest for investors $(49 \% / 0.46)$. Notably, both sets of respondent ranked it higher than "the new CEO's pay in their previous position" (42\%/0.26 for directors and 23\%/-0.21 for investors) and "the new CEO's other employment options" (58\%/0.55 and 43\%/0.26). If participation (IR) were the only constraint, then pay only needs to be enough to persuade the new CEO to leave her prior position and choose the firm over alternative opportunities. Instead, the results suggest that pay at peer firms is relevant even if the CEO could not get a job at these firms, e.g. due to there being no vacancies. Several interviewees argued that peer pay affects the CEO's perception of her worth to the firm. One noted that a CEO interacts with CEOs of competitors, customers and suppliers, and her sense of worth is eroded if she is paid much less. Thus, peer pay may determine what the CEO views as fair and be a reference point included in $\boldsymbol{X}$. Investors viewed all three of the above determinants as less important than directors, consistent with them placing less weight on labor market conditions.

The free-text fields highlighted an additional determinant of pay absent from most models internal equity considerations. One director emphasized the importance of "the multiple of the CEO pay to the average within the company"; another responded that "internal proportionality is most important." Several investors made similar statements.

\subsection{Increases in Pay for an Incumbent CEO}

Q4 asks "What causes you to increase the target quantum of pay for an incumbent CEO?" Table 8 illustrates the results; as with the prior question, there is general agreement between directors and investors. Both rated "good recent CEO performance" the highest, with support of 76\%/0.98 from 
directors and 75\%/1.05 from investors. While intuitive, it may seem unnecessary to reward high performance with increased target pay, given that almost all CEOs have substantial equity holdings. Empirically, the incentives from changes in the level of pay are so small compared to those provided by CEOs' equity holdings (Jensen and Murphy, 1990; Hall and Liebman, 1998) that they are typically ignored when calculating incentives.

The free text responses and interviews suggest that pay rises are not used to provide ex-ante incentives but to deliver ex-post recognition. A fund manager explained in an interview that pay rises are important to acknowledge good performance, and that no talented person stays in a job where she does not feel appreciated. Another pointed out that a pay rise is so small compared to firm value that it costs the company very little. Thus, if the CEO is denied it, she infers that the board and shareholders do not value her highly and may leave or be demotivated. ${ }^{14}$ This role of pay increases can be interpreted as a version of Akerlof"s (1982) "gift exchange" model. Here, it is the CEO who first gives a gift (good performance) and views it as unfair if she is not repaid with a gift of higher pay.

These findings help us refine the notion of fairness used by CEOs. Existing research on fairness does not differentiate between flow pay and changes in wealth. In experimental settings, subjects have no pre-existing wealth and only receive flow pay; researchers do not study whether changes in wealth have the same effect. ${ }^{15}$ If flow pay and changes in wealth are fungible, fairness concerns would not necessitate pay increases, since a CEO's equity already rises upon good performance.

Our results suggest instead that flow pay plays a special role in addressing CEOs' fairness concerns by providing recognition. A pay increase provides internal recognition because, unlike the revaluation of equity, it requires a discretionary decision by the board and must be approved by shareholders. It provides external recognition because it is observable and thus boosts the CEO's

\footnotetext{
${ }^{14}$ A separate reason for increasing pay is to retain the CEO if good performance increases her outside options. However, the support for "increased threat of CEO leaving" (43\%/0.25 for directors and 30\%/-0.06 for investors) was much lower.

${ }^{15}$ Fehr, Goette, and Zehnder (2009) survey the evidence for the importance of fairness in employee pay.
} 
reputation. Several interviewees explained that a pay rise is a more public endorsement than the revaluation of equity, since it is disclosed as part of the "single figure".

These responses suggest that the CEO's perception of her contribution to her firm determines another reference point included in $\boldsymbol{X}$. This is also a potential micro-foundation for why CEOs might have higher discount rates than shareholders - not because they need pay for consumption, but because changes in current pay lead to perceptions of fairness and recognition.

All other responses received less than 50\% support from both directors and investors. The second most common response from directors was "increases in firm size" $(46 \% / 0.37 ; 45 \% / 0.17$ from investors). Some free-text comments and interviewees argued that size matters because of complexity, consistent with the findings of Gayle and Miller (2009). Others explained that CEOs benchmark their pay against peers of similar size to assess whether it is fair. As one director argued, "benchmarking gives comfort that there's fairness, transparency, and objectivity." ${ }^{\prime 16}$ One potential reason is that firm size and peer firm pay are more observable than other potential determinants of pay, such as CEO talent or disutility, so linking pay to them gives the CEO comfort that pay is set fairly.

Directors ranked "increases in pay at peer firms" (44\%/0.26) significantly higher than investors (27\%/-0.17), again consistent with directors perceiving labor market pressures to be stronger. Some investors were strongly opposed to responding to increases in peer firm pay. Both sets of respondent considered peer firm pay a far less important determinant of changes in pay for an incumbent than for the pay of a new CEO. This is consistent with Kahneman, Knetsch, and Thaler's (1986) evidence on the reference point employees use to assess whether pay is fair - peer firm pay for new hires, and last year's pay for incumbents.

\footnotetext{
${ }^{16}$ In assignment models, such as Gabaix and Landier (2008), an increase in firm size does not lead to an increase in pay if the firm retains the same CEO and her talent is unchanged - since her outside option is unaffected, pay should not rise.
} 
What came out of the free-text fields is that significant increases in the level of CEO pay are surprisingly difficult. Many directors believe that large pay increases risk controversy, unless there has been a visible change to the size or complexity of the firm that can be used as justification. One director explained that "It is pretty much impossible to increase the target pay of an incumbent CEO in the UK. It might be possible with a large acquisition that changes the scale and complexity substantially"; another stated that "substantial increases would only come if the job gets markedly bigger/more complex, or there is large market shift in the way such jobs are valued."

In the same vein, and consistent with the free-text entries for Q3 (Table 7), several free-text responses argued that it was difficult to increase CEO pay significantly faster than overall workforce pay. This suggests that fairness concerns also matter for directors and investors, not just the CEO. Thus, their perceived cost of compensation may be not only the direct cost $c$, but $c+g(c, \boldsymbol{Y})$ where $g$ is a function and $\boldsymbol{Y}$ is a vector of reference points (potentially different from $\boldsymbol{X}$ ), such as worker pay, CEO pay in peer firms, or last year's pay, and. These fairness concerns may arise either because directors and investors are concerned about fairness themselves, or believe that other stakeholders are, such as employees, customers, and - for investors - their clients.

\subsection{Decreases in Pay for an Incumbent CEO}

We now turn to decreases in pay. We first asked directors, in Q5a, "Have you ever significantly decreased the target quantum of pay for an incumbent CEO?” Table 9, Panel A shows that only 23\% of directors responded "Yes." ${ }^{17}$ Combined with the difficulty in significantly increasing pay, this suggests that directors' main decision variable is the change in pay rather than the level, analogous to the findings of Lintner (1956) and Brav et al. (2005) for dividend policy. We interviewed directors to

\footnotetext{
${ }^{17} 65 \%$ of investors responded "Yes" to the analogous question "Have you ever requested significant decreases to the target quantum of pay for an incumbent CEO?" This $65 \%$ is not directly comparable to the $22 \%$ response from directors, since investors hold stakes in many companies and so are more likely to have requested decreases in at least one firm.
} 
understand why pay cuts are so infrequent. One stated that if there were ever a justification for cutting the CEO's target level of pay, you would instead fire her. Another director explained that a pay cut communicates that the board has downgraded its assessment of the CEO's worth, and a third said that, as a consequence, cutting a CEO's pay is effectively firing her. Thus, CEOs are believed to react negatively to pay cuts, suggesting that another reference point in $X$ is the prior year's pay.

To the respondents who answered "Yes", Q5b asked "What caused you to decrease the target quantum of pay for an incumbent CEO?" Here, unlike for increases in pay, there were significant discrepancies between investors and directors. The five factors that standard theories predict should drive reductions in pay (poor CEO performance, decreases in firm size, changes in attractiveness at your firm, changes in attractiveness at other firms, decreases in pay at peer firms) were the five least popular options for directors, with all average ratings being negative. In contrast, the investor responses were similar as for increases in pay - investors believe that these factors should drive both increases and decreases in pay symmetrically, just as theory predicts.

One potential explanation for this asymmetry is that directors are more concerned about the motivational or retention consequences of pay cuts. Investors' most popular reason to cut pay was poor CEO performance $(70 \% / 0.96)$, but such a cut may erode the CEO's sense of worth. CEOs may also see pay cuts because of changes in pay at peer firms or their own job getting easier as unfair, as these changes are out of their control. Recall, however, that directors view increases in peer firm pay and job complexity as valid justifications for pay rises. This echoes Garvey and Milbourn (2006), who find that CEOs are rewarded for good luck but not penalized for bad luck.

Instead, directors' three most common reasons to cut pay had no analogy in the question about increases (Q4). The most popular response (46\%/0.15, versus $27 \% /-0.28$ for investors) was "external pressure to reduce pay." The free-text responses highlighted two recent causes of external pressure the COVID-19 pandemic, and the controversy about executive pensions. A second popular reason 
was "your firm encountering financial constraints" (51\%/0.07 for directors, $58 \% / 0.53$ for investors). This was one of the few responses that differed according to firm size $(35 \% /-0.50$ for directors in the FTSE 100 versus 78\%/1.00 for FTSE Small Cap firms), consistent with financial constraints being more important and CEO pay being a larger fraction of profits in smaller firms.

A third, and unexpected, justification to cut pay was "the CEO requesting it" (41\%/-0.37). ${ }^{18}$ While contrary to almost any model, it can be justified by either the CEO having a sense of fairness or wanting to pre-empt controversy. One director wrote: "I was the incumbent CEO and asked for a reduction to reflect reduced complexity and intensity of role." Another director said that it should not be up to the board to be tough on pay; a CEO should be tough on her own pay to show that she is sensitive to the environment. Taking these three reasons together, directors see pay cuts as plausible if they can be attributed to external pressures or financial constraints, or are requested by the CEO. The likely reason is that such cuts, unlike cuts in response to bad performance, do not challenge the CEOs' sense of her worth.

In their free-text responses, several investors stressed another justification for pay decreases absent from standard models - that pay is simply too high, and thus cuts are justified even without any change in circumstances: "the total compensation is unreasonably high", "the quantum of pay was insanely high relative to anything - a formula gone wrong." In shareholder value models, pay is always set optimally, so it should only change when parameters change. In contrast, many investors believe that pay was not optimal to begin with. There were no such free-text responses from directors.

\subsection{Why Is CEO Pay So High?}

Our final questions on the level of pay aim to understand why CEO pay is so high. These are difficult questions to ask directly, as many formulations might lead to directors claiming that high

\footnotetext{
${ }^{18}$ We did not offer this response to investors as the CEO would make such a request to the board, not to them.
} 
pay is justified by CEO ability or market forces. We thus asked "If your firm reduced the target quantum of pay of its next CEO by $1 / 3$ compared to its current CEO, what might happen?" We focused on CEO transitions as this is when a board has greatest flexibility to reset CEO pay. We chose a reduction of $1 / 3$ in total pay because it is large yet not implausible. In the vast majority of companies, such a reduction would still leave the CEO being the highest-paid employee.

Table 10 illustrates the results, and again shows a significant disparity between directors and investors. Only $10 \%$ of directors agreed that "there would be no adverse consequences" (average score -0.96). Their strongest concern was "we would recruit a lower quality CEO" $(59 \% / 0.66)$. Several respondents emphasized that reducing the pay of one firm in isolation without corresponding reductions in the market would be dangerous. This indicates that they believe their CEO talent pool to be shallow, consistent with prior evidence that many firms struggle to replace CEOs who depart for exogenous reasons (e.g., Jenter, Matveyev, and Roth, 2021). ${ }^{19}$

Directors' second greatest concern was "the CEO would be less motivated" $(46 \% / 0.38)$. This is consistent with Table 5, Panel B, and suggests that the level of pay has motivational consequences missing from standard models. Just over half agreed that "it would create undesirable pay compression between the CEO and other executives" (51\%/0.36). This concern is also absent from most models, which focus on CEO pay in isolation. One potential mechanism is that compression reduces tournament incentives (Lazear and Rosen, 1981; Kale, Reis, and Venkateswaran, 2009). However, this reason was cited only once in free-text fields or interviews.

The free-text fields and interviews instead suggested that pay disparity is required for fairness the CEO is worth more to the firm than other executives or suffers more disutility. One interviewee explained that "the more you do for the company, the more you should be paid; if the CEO isn't doing

\footnotetext{
${ }^{19}$ This also reconciles our results with Table 5, Panel B, where only $13 \%$ of directors stated that constraints that lowered pay led to them hiring a less expensive CEO. Several UK firms recently reduced pay due to market-wide constraints (COVID-19 and the pressure on pensions), and the decreases were much smaller than 1/3.
} 
more, she shouldn't be CEO". Another highlighted that CEOs are under even more pressure and public scrutiny than others. A third explained that reduced pay disparity would "disrupt the natural order of things and the hierarchies within the organization", and that this concern applies beyond the CEO. If a CFO were paid less than the commercial director, even if this were dictated by market forces, the finance function would view itself as being less important.

Thus, while prior responses suggest that directors want CEO pay to not exceed certain levels, these additional fairness concerns imply that pay should also not fall short of other reference points. One potential functional form for $g(c, \boldsymbol{Y})$ may be $g_{l}\left(c-y_{1}\right)+g_{2}\left(c-y_{2}\right)$, where $g_{l}($.$) exhibits a$ discontinuous increase at 0 (the cost of CEO pay increases if it is disproportionate to worker pay or shareholder returns), and $g_{2}($.) exhibits a discontinuous decrease at 0 (the cost also increases if CEO pay is not sufficiently above the pay of other top executives).

Investors were much more open to cutting CEO pay than directors. Their most popular response was that "there would be no adverse consequences" (33\%/-0.02, with 35\% neither agreeing nor disagreeing). Fewer than a quarter agreed with each of the negative consequences. Thus, many investors believe that significant reductions in CEO pay are possible. Several explained that, even if the board ends up recruiting a different CEO, she would be less materialistic rather than less capable. A fund manager claimed that "CEOs should not just be motivated by quantum of compensation - that suggests they have the wrong person;" a governance specialist stated that "[the CEO] might have a hissy fit ... then the board should reconsider if this person is appropriate for the role."

The view of many investors that CEO pay is often unjustified was also reflected in their responses to Q15a: “Do you believe the overall level of CEO pay is too low, too high, or about right?” (We did not ask this question to directors due to concerns about biased responses). $77 \%$ of investors view pay as too high (Table 11, Panel A). We then asked these $77 \%$ why it is too high. $86 \%$ agreed that "boards are ineffective at lowering it even though they should," and 56\% agreed that "investors have 
insufficient power over boards to lower it" (Table 11, Panel B). Thus, many investors view CEO pay as excessive, and they blame boards for it.

\section{Summary}

Our questions on the level of pay yield the following conclusions:

1. Directors believe that significant cuts to the level of pay would markedly worsen the quality and motivation of the CEO. The level of pay affects motivation by affecting perceptions of fairness, in contrast to standard models.

2. Many investors, in contrast, believe that there would be few adverse consequences of pay cuts, even if made by one firm in isolation. Instead, they view a CEO transition as an opportunity to reset the level of pay. $77 \%$ of investors believe that pay is too high, which they mainly attribute to boards being weak.

3. Both investors and directors believe that good recent performance should increase expected pay, even though most CEOs have substantial consumption incentives from their equity holdings. Ex post recognition of performance is seen as important because CEOs care about fairness and reputation.

4. Directors view themselves as not starting from a blank sheet of paper. They believe it to be difficult to increase pay, and even more difficult to decrease pay, in response to firm-specific changes or changes in the outside option. In contrast, investors believe that such changes should drive both increases and decreases in pay.

5. Ability is seen as the most important determinant of a new CEO's pay. The (dis)utility of a CEO job is another important driver, suggesting significant cross-sectional variation.

6. Pay in peer firms affects new CEO pay even more than alternative employment opportunities and the pay at the CEO's prior job. This appears to be because peer firm pay affects what is viewed as fair, rather than because of labor market competition. 
7. CEO pay levels are affected by internal comparisons. Directors and investors believe there should be a substantial gap to other top executives, but also that the gap to the wider workforce should not be too large.

\section{The Structure of Pay}

This section studies the structure of pay. In Section 6.1, we first ask what directors and investors believe motivates a CEO. Section 6.2 asks why companies offer variable pay, and Section 6.3 targets the split between fixed and variable pay. Sections 6.4 and 6.5 explore why two key predictions of contract theory are not always implemented in practice - long-term incentives and relative performance evaluation.

\subsection{What Motivates a CEO?}

Q7 asks "What motivates your CEO to perform strongly?" Table 12 shows the results, which are generally similar for directors and executives. Most models assume that financial incentives are the only motivator. While the support for "incentives from bonuses, LTIPs, equity, or future pay increases" was high ( $76 \% / 0.98$ for directors and $68 \% / 0.83$ for investors), it was only the third highestrated response for both groups.

Instead, by far the strongest perceived drivers of CEO effort were "intrinsic motivation" (92\%/1.55 for directors and 91\%/1.50 for investors) and "personal reputation" (91\%/1.40 and $96 \% / 1.60)$. Both are absent from almost all contract theories. ${ }^{20}$ Personal reputation scored highly even though we offered separate responses for the financial benefits of a superior reputation (pay increases and labor market consequences). This suggests that simply being seen to do a good job is an important aspect of reputation. An investor said that "There is a common misperception that pay or career

\footnotetext{
${ }^{20}$ Carlin and Gervais (2009) and Bettignies and Robinson (2018) are rare exceptions. Under a broad interpretation of the cost of effort $g(a)$, a lower cost of effort could capture high intrinsic motivation. Bénabou and Tirole (2003) study how extrinsic incentives affect intrinsic motivation, but not the reverse.
} 
progression motivates CEOs to do a good job. [Performance] comes from intrinsic motivation, passion for the job, and maybe a concern with reputation.”

The free-text responses suggest that incentive pay provides ex post recognition of performance, and that it interacts with intrinsic motivation and reputational concerns (we will use "intrinsic incentives" as an umbrella term for these two motivators). The CEO values incentive pay not because she needs it to afford consumption - as one investor stressed, "all CEOs are going to take care of most human needs in terms of finances" - but because it is recognition that she has performed well. One director stated that "primary motivation comes from inside, but pay is important as a signal to the CEO and the market of the value placed on them by the board." Another wrote that "relative competition (why does he earn more than me?) is very significant as an issue of pride."

"The quantum of pay" (55\%/0.55 for directors, 37\%/0.21 for investors) is seen as another important motivator, inconsistent with most theory models but consistent with the importance of fairness. ${ }^{21}$ One director explained that "principle and sense of fairness tends to matter a lot."

Finally, even though career concerns have been a focus of the literature on CEO incentives since Fama (1980), they are not seen as important by our respondents, especially directors. "The potential to move to a bigger firm" received support of only $18 \% /-0.53$ from directors $(46 \% / 0.37$ from investors), and the "risk of being fired" only $11 \% /-0.88(25 \% /-0.20)$. The lack of incentives from a potential upward move is consistent with the fact that incumbent CEOs are rarely being hired away (Cziraki and Jenter, 2021). In relation to firing risk, one interviewee explained that boards hire CEOs that are confident in their ability to succeed, so they should not be motivated by firing risk.

\footnotetext{
${ }^{21}$ This likely underestimates the effect of pay levels on motivation, since the question focused on "strong performance." If pay is a hygiene factor, a low quantum of pay demotivates, while high pay does not by itself motivate. A director explained that "most CEOs want to be paid fairly, so it's a demotivator if they aren't as opposed to a motivator."
} 


\subsection{The Motivation for Variable Pay}

In Q8, we ask "Why do you offer the CEO variable pay?” Note that practitioners interpret variable pay as elements of flow pay that are sensitive to performance, and do not include the CEO's existing equity holdings.

Table 13 reports the results. The most popular response was "to motivate the CEO to improve long-term shareholder value" (89\%/1.46 for directors and $87 \% / 1.36$ for investors). Thus, even though directors and investors believe that intrinsic incentives are the main motivators, financial incentives are important to reinforce them - in contrast to common arguments that they crowd them out. Freetext fields and interviews suggest two reasons. First, intrinsic incentives may be insufficient. As one interviewee explained, only a "superhuman" CEO would be willing to perform at her very best without financial incentives. ${ }^{22}$ Second, intrinsic incentives may lead to CEO actions that do not increase firm value. Examples given by interviewees include increasing the scale of the business, R\&D for scientific curiosity, or designing the highest-quality product even if a low-cost strategy would be more effective.

The popularity of this response is interesting also because many CEOs have substantial equity holdings. Thus, even if financial incentives are needed, it is not clear why they need to be provided by variable pay. Interviews and free text fields provided three explanations. First, pay incentives are different from portfolio incentives because they provide recognition. ${ }^{23}$ Directors explained that variable pay is used "so the CEO would directly and quickly feel the impact of good and (where relevant) poor short-term performance" and "to recognize achievement - the retrospective acknowledgement of exceptional performance is important."

\footnotetext{
${ }^{22}$ Hartzell, Parsons, and Yermack (2010) show that even church clergy receive incentive pay, despite intrinsic motivation being presumably strong.

${ }^{23}$ A complementary explanation is that variable pay is immediately received and the CEO enjoys "realization utility" (Barberis and Xiong, 2012). Even though the CEO's equity holdings rise in value with good performance, the CEO cannot realize this gain for many years due to vesting and holding periods.
} 
The second reason is that other employees are offered variable pay. One director pointed out that "variable pay is an organization wide practice ... difficult to think of CEO scheme in isolation," another that "a high proportion of variable pay runs through all levels of the organization (commission at lower levels, bonuses at higher levels) and it therefore feels appropriate and a cultural alignment for the CEO to have a high mix of variable pay." While internal equity comparisons are typically about the level of pay (e.g., pay ratios), the comparison of pay structures has received less attention.

The third reason is that variable pay can be based on criteria other than the stock price. One director explained how CEOs are set business plans with key performance indicators (“KPIs”), and that tying pay to these KPIs holds management accountable. He also noted that CEO actions have a greater effect on these KPIs than the stock price. Another director argued that the company's KPIs are only credible to employees and investors if they are incorporated into the CEO's contract. Thus, even if KPIs ultimately improve the stock price, so the stock price is a "sufficient statistic", there might be value to including KPIs in the contract to create a performance culture within the firm.

The second-most popular rationale for incentive pay among investors $(79 \% / 1.14)$ and third-most among directors $(84 \% / 1.16)$ was a response strongly contradicted by theory: "so that the CEO shares risks with investors and stakeholders, even if out of the CEO's control." While this implies inefficient risk-sharing, several respondents argued that it is unfair to insulate CEOs from a downturn. Free-text fields emphasized the importance of "shareholder alignment" and "to mirror shareholder experience." One investor, in an interview, said that CEOs should be co-owners as they will be "there for the journey"; in a downturn, "it's not fair that I have to take the pain and you don't." Thus, one reference point in $\boldsymbol{Y}$, the vector that directors and investors use to assess fairness, may depend on shareholder returns. While theoretically a board could argue “we're not cutting the CEO's pay because she's riskaverse; by insulating her from downturns outside her control, we were able to pay her less in expected 
value terms," investors and stakeholders are unlikely to accept such an argument - particularly since they do not see the counterfactual contract that would have been offered without this insurance.

A rationale for incentive pay studied by in standard models is screening (e.g., Lazear (2005)), which we tested with "to attract/retain a high-ability or hard-working CEO." This also received strong support (87\%/1.19 from directors and 69\%/0.85 from investors). We also offered a response of "to motivate the CEO to improve outcomes other than long-term shareholder value." Interestingly, there was only modest support (52\%/0.46 from directors and 53\%/0.47 from investors), despite environmental, social, and governance ("ESG") targets becoming increasingly important. Respondents may believe that alignment with long-term shareholder value already causes the CEO to take stakeholders into account, or that intrinsic incentives are sufficient. One investor wrote "What kind of outcomes, other than long-term shareholder value? Do CEOs really need incentives to 'do the right thing?" "An interviewee said that ESG targets would backfire as no targets capture the totality or even majority of ESG performance; another argued that such targets would cause the CEO to improve only the ESG dimensions in the contract.

Directors $(49 \% / 0.37)$ and investors $(15 \% /-0.45)$ disagreed on whether it is important "to match peer firm practice." This highlights an interesting paradox - recall from Table 6 that directors report that investors and their advisors (proxy agencies) force them to follow market practice more than they would like. Our results here, however, suggest that many investors appreciate heterogeneity - thus, directors may have more latitude to tailor the structure of pay than they think.

\subsection{The Determinants of Variable Pay}

In Q9, we ask "What determines the split between variable and fixed pay?" This question tests theoretical predictions for the level of incentives $\theta$. Table 14 reports the results. Unexpectedly, the lowest responses were "CEO personal risk appetite" (22\%/-0.46 for directors and 20\%/-0.45 for 
investors) and "how risky our firm is" (16\%/-0.44 and 47\%/0.29) ${ }^{24}$ These variables are key drivers of incentives in equation (4) - in theory, the higher firm risk $\sigma^{2}$ and CEO risk aversion $\eta$, the greater the compensating differential the $\mathrm{CEO}$ requires for variable pay. However, if the motivation for rewarding good performance is recognition and fairness, this trade-off is moot; instead, pay variability is driven by what is perceived to be the fair reward for performance.

The low importance respondents attached to firm risk is consistent with the mixed evidence for the link between risk and incentives summarized in Section 2, as well as with models predicting no link such as Prendergast (1992), Edmans, Gabaix, and Landier (2009), and Edmans and Gabaix (2011). The low importance attached to risk aversion is consistent with the weak relationship with incentives documented by Becker (2006).

The most popular response was "how much the CEO can affect firm performance" $(62 \% / 0.66$ for directors and $75 \% / 0.98$ for investors), which corresponds to $b$ in equation (4). While consistent with the model of Section 2, the mechanism there is that a lower $b$ causes the principal to induce less CEO effort as it is not worth it compared to the risk premium required to do so; thus, $\theta$ falls. This is inconsistent with the low support for the relevance of risk, and also the results of Table 3 that directors and investors consider incentives to be much more important than keeping the level of pay down. None of the interviews pointed to this mechanism but instead to a different one - if the CEO has a greater effect on performance, it is fair to reward her more for good performance.

The next two most popular responses from directors are not predicted by equation (4): "investor or proxy advisor expectations" $(60 \% / 0.55)$, and "the split between fixed and variable pay in peer firms" (49\%/0.37). Thus, many directors do not set $\theta$ from first principles but follow market practice. Free-text responses included "The benchmark seemed to be set at roughly a third for each of salary, bonus \& shares. 'This is what everyone else does'" and "RemCos are being increasingly forced to

\footnotetext{
${ }^{24}$ Beta testing identified "risk appetite" as the best way to translate "risk aversion" into practitioner language.
} 
'fit' genuine motivational adjustments to pay into a rigid framework [...] governed by superficial numerical comparisons with other companies." Again, this is surprising given that investors claim that they do not consider peer firm practices as important (Table 13).

\subsection{Long-Term Incentives}

Classic theories of managerial myopia (e.g., Stein (1988)) highlight the erosion of shareholder value that arises if CEO pay is tied to the short-term stock price. A natural solution is to pay the CEO according to long-term performance (Edmans et al., 2012). Even if the CEO demands a compensating differential for the greater risk, this may be outweighed by the benefits of superior decisions. However, horizons are short in practice (Gopalan et al., 2014) and lead to CEOs taking actions to boost short-term profits and stock prices (Edmans, Fang, and Lewellen, 2017; Ladika and Sautner, 2020). Q10 studies the reasons for this apparent disconnect between theory and practice, asking "What would happen if you made the CEO's incentives more long-term?"

Table 15 reports the results. By far the most popular response from investors was "the CEO would make better decisions" $(78 \% / 1.14)$. In contrast, the three responses that suggest negative consequences - "the incentives would lose their effectiveness", "we would have to pay the CEO more, which would outweigh any benefits", and "we would be unable to attract/retain the CEO we want" all scored below -0.8 , with at most $6 \%$ agreeing with each concern. ${ }^{25}$ As one fund manager wrote, "This would be a win win win win win. It would weed out CEOs that are in it for a quick buck, it would focus on long-term outcomes, and it would align CEOs with shareholders. If I could have a single bullet to improve corporate governance, this would be it." Another said that "We would get

\footnotetext{
${ }^{25}$ One potential reason for the low response to the last option is that more long-term incentives may have opposite effects on attraction and retention. They may deter a CEO from joining, but once a CEO has joined they may encourage retention if forfeited upon departure (Jochem, Ladika, and Sautner, 2018).
} 
better alignment between $\mathrm{CEO}$ and owners. It is ridiculous that industries with a 5, 10, 15 year business/product cycle have a 1 and 3 year incentive program."

Directors view the world very differently. "The CEO would make better decisions" obtained the weakest response $(21 \% /-0.40)$, while the three other responses stating concerns scored between 0.1 and 0.2 , with $38-44 \%$ agreeing with each. In the free text fields, some directors explained that the incentives they provide are already sufficiently long-term and that further lengthening would reduce their effectiveness. Others argued that shareholders are short-termist and would object. This discrepancy between investors' stated preferences and directors' views of investor preferences is interesting, and echoes the mismatch on investors' preferences for tailoring.

\subsection{Relative Performance Evaluation}

Holmstrom (1982) showed that performance should be benchmarked against peers, to filter out fluctuations caused by external factors. Doing so would reduce the CEO's risk, allowing the board to lower the cost of compensation. While recent studies show that the use of relative performance evaluation ("RPE") is greater than in the past (see the survey by Edmans, Gabaix, and Jenter (2017)), it is far from universal. Indeed, in their critique of CEO pay, Bebchuk and Fried (2004) highlighted the lack of RPE as prime evidence for rent extraction.

To study this practice, Q11a asks "Do you filter out industry conditions from all performance measures (e.g. by benchmarking against peers)?" Table 16 reports the results. $63 \%$ of directors and 75\% of investors responded "No." To those respondents, Q11b asks why they believe universal benchmarking to be undesirable. The most popular answer among directors $(43 \% / 0.44$, versus $33 \% / 0.05$ from investors) was that "the CEO should benefit from an industry upswing, since investors and stakeholders do." This response contradicts efficient risk-sharing, but is consistent with notions of fairness in two ways. First, if investors have benefited from windfalls due to good market 
conditions, it may be seen as fair for the CEO to also benefit. Second, not benchmarking on the downside (see Table 13) means it is fair not to do so on the upside.

The next two highest responses from directors were "It is too difficult to define an appropriate peer group" (43\%/0.20, versus 29\%/-0.06 for investors) and "We don't have information on peer performance for some measures" $(47 \% / 0.17,34 \% /-0.12)$. These are considerations absent from all models, which assume that a peer group exists and peer performance is observable. One director explained that "for a large firm, there are few if any comparators which are similar enough." An interviewee gave the example of the mining sector, where there are only three large players (BHP, Anglo American, and Rio Tinto) with very different portfolios. On the observability of peer performance, one director wrote that "particularly non-financial measures are hard to benchmark."26

Investors responded most positively to "benchmarking all performance measures would lead to the CEO mimicking peers" (41\%/0.14), but directors did not (27\%/-0.23). The model of Zwiebel (1995) showed that benchmarking could lead to the CEO taking insufficient good risk, but the freetext responses did not raise this concern. Instead, they pointed out that mimicry could lead to firms taking excessive bad risk (such as over-leveraging if peers are over-leveraging) or short-termist actions (cutting investment to boost margins if peers are doing so).

We also explored other theories for the lack of RPE - "Relative performance measures are less motivating for the CEO" (Dittmann, Maug, and Spalt, 2013), "In an industry upswing, not benchmarking performance keeps our pay competitive with peers" (Oyer, 2004), and "The CEO is responsible for choosing which industries our firm operates in” (Gopalan, Milbourn, and Song, 2010) - but these theories received little support.

\footnotetext{
${ }^{26}$ Another, in an interview, pointed out that some measures of peer performance are only observable with a lag in the peer's annual report.
} 
There are more complex theories of pay-for-luck. For example, Axelson and Baliga (2009) show that, for a contract to be renegotiation-proof, the CEO must have private information that causes her to have a different view from the board on the value of her long-term pay. Industry prospects are an example of such private information, and so it can be efficient to make the contract contingent upon them. We did not test such theories because of the "as if" critique - they are so intricate that respondents may be unaware they are a driver. It may be that these alternative theories do explain pay-for-luck in reality. However, applying Occam's razor, the inability to define an appropriate peer group or observe performance may be the more important reason for many firms.

\subsection{Summary}

Our questions on the structure of pay yield the following conclusions:

1. Directors and investors consider intrinsic motivation and personal reputation to be the most important sources of incentives for CEOs.

2. While the primary reason for variable pay is to motivate the CEO to improve long-term shareholder value, this is not because the CEO obtains utility from consuming the additional pay from good performance. Instead, variable pay provides ex post recognition of good performance, addressing the CEO’s fairness concerns and boosting her reputation.

3. How much the CEO can affect firm performance is the main determinant of pay variability. Directors view peer firm practice and investor or proxy advisor expectations as important constraints, hindering them from tailoring pay - even though investors themselves do not consider following peer practice as important. Firm risk and CEO risk aversion are not important determinants.

4. Investors strongly believe that lengthening the horizon of CEO incentives would improve decision making, with few adverse consequences. Directors disagree. Some directors are 
concerned about the attraction/retention effects of such a change; others believe that incentives would become less effective.

5. The majority of directors and, in particular, investors, believe that benchmarking of CEO performance measures should not be universal. One reason is that it is fair for CEO pay to mirror the shareholder experience. A second is that, for many companies, it is difficult to define an appropriate peer group or obtain information on peer performance.

\section{Who Sets CEO Pay?}

Our final set of questions explores who sets CEO pay. We asked investors Q16: "How much influence do you believe investors have on CEO pay?", with -2 representing no influence and 2 representing high influence. Table 17 shows the results. Fewer than $5 \%$ of investors view themselves as having high influence, despite having a legally binding vote on policy, with $35 \%$ selecting 1 and $40 \%$ choosing 0 . An investor argued that the board often views itself as an agent of regulators concerned with fulfilling its legal requirements, rather than as an agent of shareholders.

Q14 broadens the question to other parties. We asked "How much do the following influence CEO pay compared to the optimal level?", where -2 represents "much less than they should", 0 "about right", and 2 "much more than they should." Table 18 shows the results. $72 \%$ of directors believe proxy advisors' influence to be excessive (average score of 1.00). Even though Table 4 showed that directors view investors as the most severe source of constraints, only $37 \%$ of directors see investors' influence as excessive, with 57\% rating it as "about right." Directors may view investors' influence as more legitimate because they own shares in the company.

Just as directors view investors' advisors (proxy agencies) as having the most excessive influence, investors think the same about directors' advisors (compensation consultants), with scores of $70 \% / 0.97$. The free text fields show that each blames the other's advisors for similar behavior - 
excessive benchmarking to peers and insufficient tailoring to a particular situation. Shareholders also view CEOs $(64 \% / 0.80)$ as having too much influence on CEO pay, echoing earlier responses suggesting they view boards as weak.

Unsurprisingly, investors think that they have too little influence $-62 \%$ report that their influence is "less" or "much less" than it should be. This is, in part, because shareholders view other shareholders as not influencing pay in the way they should. One argued that "investors have surprisingly little influence over CEO pay. The biggest ones - the index investors - are even worse as they try and force a one size fits all approach to all companies." This echoes the responses in Table 4, where $44 \%$ of investors believe that other investors cause firms to offer contracts that sacrifice shareholder value.

Investors' dissatisfaction with CEO pay may be surprising since average say-on-pay support consistently exceeds $90 \%$ in the UK. ${ }^{27}$ We explored this incongruity in interviews and received several explanations. Multiple investors responded that say-on-pay is viewed as a vote on the CEO's performance, rather than on CEO pay. Thus, if the CEO has performed well, investors will support her pay even if it is high. Second, many investors follow proxy advisors and vote for if the advisor recommends it; due to resource constraints, they focus their attention on cases with negative recommendations. Third, investors wishing to have a constructive relationship with management prefer to address concerns through engagement rather than voting against. Finally, if an investor has voted against, the company will repeatedly ask to meet in the future to seek the investors' approval of pay, imposing a significant time cost. This is the opposite of the concern typically voiced in the literature - that voting against management may reduce investor access.

\footnotetext{
${ }^{27}$ For example, in 2020, average support for the implementation vote exceeded $93 \%$ for both the FTSE 100 and FTSE 250 (Equiniti’s Annual Review of AGM Trends 2020).
} 


\subsection{Summary}

Our questions on who sets CEO pay yield the following conclusions:

1. Investors believe that they have insufficient influence on CEO pay, with fewer than $5 \%$ believing that shareholder influence is high. Some view other shareholders as not influencing pay in the right direction. In contrast, $37 \%$ of directors believe that investors have more influence than they should, and 57\% believe that investor influence is at the right level.

2. Both directors and investors believe that each other's advisors (compensation consultants and proxy agencies, respectively) have more influence than they should, causing excessive benchmarking and insufficient tailoring to company specifics.

3. Investors believe that CEOs have too much influence on their own pay. Some investors view say-on-pay votes as an evaluation of CEO performance, and thus are reluctant to vote against pay if performance has been good.

\section{Conclusion}

This paper surveyed directors and investors on the objectives, constraints, and determinants of CEO pay. Our results show that many standard assumptions of executive pay models do not describe how pay is actually set, and we suggest alternative assumptions to bring the models closer to reality.

Boards face a much broader set of constraints than participation and incentive compatibility, frequently causing them to offer lower levels of pay and more one-size-fits-all structures than they prefer. The strongest constraint is the need to obtain shareholder approval, suggesting that directors and investors disagree on how to maximize shareholder value. Investors perceive the need to avoid controversy with employees, customers, and policymakers as important additional constraints.

Even for the standard constraints of participation and incentive compatibility, there is significant disagreement on their importance. Investors believe incentives could be tightened and the 
participation constraint to be slack. They wish boards to take tougher stances on the level of pay and align the structure more to long-term shareholder value. In contrast, directors believe that the participation constraint is close to binding. They feel that investors underestimate the difficulties of attracting and retaining CEOs in the managerial labor market, and that implementing investors' wishes would demotivate the CEO or precipitate her departure.

Turning to the determinants of pay, we find that fairness concerns play an important role in both the level and structure of CEO pay. Starting with the level of pay, investors and especially directors believe that the CEO needs to be paid at competitive levels, even absent any recruitment or retention concerns, because the failure to do so would be viewed as unfair and undermine the CEO's intrinsic motivation. CEOs are believed to assess their pay against their expectation of a fair reward, rather than based only on the consumption utility it provides.

Moving to the structure of pay, both directors and investors believe that pay should be linked to performance, even though they view financial incentives as less important motivators than intrinsic motivation and the CEO's personal reputation. Financial incentives are believed to interact with these other drivers - not being rewarding for good performance would be seen as unfair by the CEO and undermine her motivation, but visibly doing so reinforces it. This suggests that incentive pay is valuable because it provides ex post recognition of performance, in addition to consumption incentives. This in turn implies that pay incentives, by delivering greater recognition, play a special role over and above portfolio incentives, whereas standard models view them as fungible.

The survey responses and interviews identify two other fairness considerations that explain the link between pay and performance. One is that CEOs are expected to share external shocks with investors and stakeholders, in contrast to optimal risk-sharing. A second is that, if employees' pay is linked to their performance, it is fair for the CEO's pay to be similarly sensitive. 
Our results point towards a considerably more complex but also more interesting model of CEO pay than currently used in the academic literature. Investors and especially directors believe that CEOs evaluate their compensation relative to a set of reference points, such as the pay of other CEOs, their past pay, and their perceived contribution to the firm. In turn, directors and investors evaluate CEO pay relative to a set of potentially different reference points, such as the pay of other CEOs, past CEO pay, the pay of employees and other top executives, and shareholder returns.

Our findings suggest a number of potential directions for future research. Starting with theory, the standard assumption of a single principal - a shareholder-aligned board - does not capture the complexity of the pay-setting process. The opposite assumption of the board maximizing pay, implicit in the "rent-extraction" view, is also unrealistic. Instead, pay is often set by a board that sees itself as maximizing shareholder value, but that also must obtain the approval of shareholders who have different information, beliefs, or objectives. Our results also call for models where pay is influenced by fairness concerns, felt by investors, directors, and CEOs, with a multitude of potential reference points. Separately, the perceived difficulty of changing contracts due to history or pay policy restrictions suggests the value of research on "detail-free" incentive contracts, that are robust to changes in the environment (e.g., Chassang, 2013).

Theorists may consider some of the practices we document here - such as following peer practice rather than designing contracts from first principles - as suboptimal and would like to study how pay "should" be set. If so, they should acknowledge that their models are normative rather than positive. As a result, it may not be appropriate to evaluate them according to their empirical consistency but instead the realism of their assumptions, which our survey helps guide.

The survey results also suggest that certain inefficient features of observed contracts may not be as puzzling as previously believed, so they may not need to be "explained" by future models. For example, if pay-for-luck is indeed determined by fairness considerations and the difficulty of defining 
a peer group and observing peer performance, then there is less need for models justifying pay-forluck. Similarly, if variable pay is driven by the need to provide recognition rather than consumption incentives, the mixed evidence on the link between incentives and risk is less puzzling.

Future empirical analyses might further distinguish between the "weak/uninformed boards" and "uninformed investors" explanations for the disagreements between directors and investors. For example, researchers could study how deep the labor market for CEOs actually is, and what are the consequences (for either CEO retention or performance) of changes to the level or structure of pay that make the contract less attractive. These consequences might differ according to whether these changes are made to one firm in isolation, or across the board. Another implication is that pay incentives and portfolio incentives may not be fungible and thus should be separated out in empirical analyses. Finally, it would be fruitful to study how important fairness is in executive pay, and what reference points CEOs, directors, and investors use to assess whether CEO pay is fair. 


\section{References}

Akerlof, George A. 1982. Labor Contracts as Partial Gift Exchange. Quarterly Journal of Economics 97, 543-569.

Albuquerque, Ana M., Rui Albuquerque, Mary Ellen Carter, and Qi (Flora) Dong. 2020. Are CEOs Paid Extra for Riskier Pay Packages? Working Paper, Boston University.

Barberis, Nicholas and Wei Xiong. 2012. Realization Utility. Journal of Financial Economics 104, 251-271.

Bebchuk, Lucian A. and Jesse M. Fried. 2004. Pay Without Performance: The Unfulfilled Promise of Executive Compensation. Cambridge: Harvard University Press.

Becker, Bo, 2006. Wealth and Executive Compensation. Journal of Finance 61, 379-397.

Ben-David, Itzhak, John R. Graham, and Campbell R. Harvey. 2013. Managerial Miscalibration. Quarterly Journal of Economics 128, 1547-1584.

Bénabou, Roland and Jean Tirole. 2003. Intrinsic and Extrinsic Motivation. Review of Economic Studies 70, 489-520.

Bertrand, Marianne and Sendhil Mullainathan. 2001. Are CEOs Rewarded for Luck? The Ones Without Principals Are. Quarterly Journal of Economics 116, 901-932.

Bettignies (de), Jean-Etienne and David T. Robinson. 2018. When is Social Responsibility Socially Desirable? Journal of Labor Economics 36, 1023-1072.

Brav, Alon, John R. Graham, Campbell R. Harvey, and Roni Michaely. 2005. Payout Policy in the $21^{\text {st }}$ century. Journal of Financial Economics 77, 483-527.

Brown, Martin, Armin Falk and Ernst Fehr. 2004. Relational Contracts and the Nature Of Market Interactions. Econometrica 72, 747-780.

Cabezon, Felipe 2020. Executive Compensation: The Trend Toward One Size Fits All. Working Paper, University of Southern California.

Carlin, Bruce Ian and Simon Gervais. 2009. Work Ethic, Employment Contracts, and Firm Value. Journal of Finance 64, 785-821.

Chassang, Sylvain, 2013. Calibrated Incentive Contracts. Econometrica 81, 1935-1971.

Coles, Jeffrey L., Naveen D. Daniel, and Lalitha Naveen. 2006. Managerial Incentives and RiskTaking. Journal of Financial Economics 79, 431-468.

Cziraki, Peter and Dirk Jenter. 2021. The Market for CEOs. Working Paper, University of Toronto.

Dasgupta, Amil, Vyacheslav Fos, and Zacharias Sautner. 2021. Institutional Investors and Corporate Governance. Foundations and Trends in Finance, forthcoming. 
Dittmann, Ingolf, Ernst Maug, and Oliver Spalt. 2013. Indexing Executive Compensation Contracts. Review of Financial Studies 26, 3182-3224.

Edmans, Alex, Vivian W. Fang, and Katharina A. Lewellen. 2017. Equity Vesting and Investment. Review of Financial Studies 30, 2229-2271.

Edmans, Alex and Xavier Gabaix. 2016. Executive Compensation: A Modern Primer. Journal of Economic Literature 54, 1232-1287.

Edmans, Alex and Xavier Gabaix. 2011. Tractability in Incentive Contracting. Review of Financial Studies 24, 2865-2894.

Edmans, Alex, Xavier Gabaix, and Augustin Landier. 2009. A Multiplicative Model of Optimal CEO Incentives in Market Equilibrium. Review of Financial Studies 22, 4881-4917.

Edmans, Alex, Xavier Gabaix, Tomasz Sadzik, and Yuliy Sannikov. 2012. Dynamic CEO Compensation. Journal of Finance 67, 1603-1647.

Edmans, Alex, Xavier Gabaix, and Dirk Jenter. 2017. Executive Compensation: A Survey of Theory and Evidence. In: Handbook of the Economics of Corporate Governance Chapter 9, 383-539.

Faleye, Olubunmi, Ebru Reis, and Anand Venkateswaran. 2013. The Determinants and Effects of CEO-Employee Pay Ratios. Journal of Banking and Finance 37, 3258-3272.

Fama, Eugene F. 1980. Agency Problems and the Theory of the Firm. Journal of Political Economy $88,288-307$.

Fehr, Ernst, Lorenz Goette, and Christian Zehnder. 2009. A Behavioral Account of the Labor Market: The Role of Fairness Concerns. Annual Review of Economics 1, 355-384.

Fernandes, Nuno, Miguel A. Ferreira, Pedro Matos, and Kevin J. Murphy. 2013. Are US CEOs Paid More? New International Evidence. Review of Financial Studies 26, 323-367.

Friedman, Milton. 1953. The Methodology of Positive Economics. In: Essays in Positive Economics, edited by Milton Friedman. Chicago: University of Chicago Press.

Gabaix, Xavier, and Augustin Landier. 2008. Why Has CEO Pay Increased So Much? Quarterly Journal of Economics 123, 49-100.

Garvey, Gerald T. and Todd T. Milbourn. 2006. Asymmetric Benchmarking in Compensation: Executives are Rewarded for Good Luck but not Penalized for bad. Journal of Financial Economics 82, 197-225.

Gayle, George-Levi and Robert A. Miller. 2009. Has Moral Hazard Become a More Important Factor in Managerial Compensation? American Economic Review 209, 1740-1769.

Gompers, Paul, Will Gornall, Steven N. Kaplan, and Ilya A. Strebulaev. 2020. How Do Venture Capitalists Make Decisions?. Journal of Financial Economics 135, 169-190. 
Gopalan, Radhakrishnan, Todd Milbourn, and Fenghua Song. 2010. Strategic Flexibility and the Optimality of Pay for Sector Performance. Review of Financial Studies 23, 2060-2098.

Gopalan, Radhakrishnan, Todd Milbourn, Fenghua Song, and Anjan V. Thakor. 2014. Duration of Executive Compensation. Journal of Finance 69, 2777-2817.

Graham, John R. and Campbell R. Harvey. 2001. The Theory and Practice of Corporate Finance: Evidence from the Field. Journal of Financial Economics 60, 187-243.

Graham, John R., Campbell R. Harvey, and Manju Puri. 2013. Managerial Attitudes and Corporate Actions. Journal of Financial Economics 109, 103-121.

Graham, John R., Campbell R. Harvey, and Shiva Rajgopal. 2005. The Economic Implications of Corporate Financial Reporting. Journal of Accounting and Economics 40, 3-73.

Hall, Brian J. and Jeffrey B. Liebman. 1998. Are CEOs Really Paid Like Bureaucrats? Quarterly Journal of Economics 112, 653-691.

Hartzell, Jay C., Christopher A. Parsons and David L. Yermack. 2010. Is a Higher Calling Enough? Incentive Compensation in the Church. Journal of Labor Economics 28, 509-540.

Herzberg, Frederick. 1959. The Motivation to Work. New York: Wiley.

Holmstrom, Bengt. 1982. Moral Hazard in Teams. Bell Journal of Economics 13, 324-340.

Holmstrom, Bengt, and Paul Milgrom. 1987. Aggregation and Linearity in the Provision of Intertemporal Incentives. Econometrica 55, 308-328.

Iliev, Peter and Michelle Lowry. 2015. Are Mutual Funds Active Voters? The Review of Financial Studies 28, 446-485.

Jensen, Michael C. and Kevin J. Murphy. 1990. Performance Pay and Top-Management Incentives. Journal of Political Economy 98, 225-264.

Jenter, Dirk, Egor Matveyev, and Lukas Roth. 2021. Good and Bad CEOs. Working Paper, London School of Economics.

Jochem, Torsten, Tomislav Ladika, and Zacharias Sautner. 2018. The Retention Effects of Unvested Equity: Evidence from Accelerated Option Vesting." Review of Financial Studies 31, 41424186.

Jochem, Torsten, Gaizka Ormazabal, and Anjana Rajamani. 2021. Why Have CEO Pay Levels Become Less Diverse? Working Paper, University of Amsterdam.

Kahneman, Daniel, Jack L. Knetsch and Richard Thaler. 1986. Fairness as a Constraint on Profit Seeking: Entitlements in the Market. American Economic Review 76, 728-741.

Kale, Jayant R., Ebru Reis, and Anand Venkateswaran. 2009. Rank-Order Tournaments and Incentive Alignment: The Effect on Firm Performance. Journal of Finance 64, 1479-1512. 
Krueger, Philipp, Zacharias Sautner, and Laura T. Starks. 2020. The Importance of Climate Risks for Institutional Investors. Review of Financial Studies 33, 1067-1111.

Ladika, Tomislav and Zacharias Sautner. 2020. Managerial Short-Termism and Investment: Evidence from Accelerated Option Vesting. Review of Finance 24, 305-344.

Larcker, David F., Allan L. McCall, and Gaizka Ormazabal. 2015. Outsourcing Shareholder Voting to Proxy Advisory Firms. Journal of Law and Economics 58, 173-204.

Lazear, Edward P. 2005. Output-Based Pay: Incentives, Retention, or Sorting? Research in Labor Economics 23, 1-25.

Lazear, Edward P. and Sherwin Rosen. 1981. Rank-order Tournaments as Optimum Labor Contracts. Journal of Political Economy 89, 841-864.

Lintner, John. 1956. Distribution of Incomes of Corporations Among Dividends, Retained Earnings, and Taxes. American Economic Review 46, 97-113.

Malenko, Nadya and Yao Shen. 2016. The Role of Proxy Advisory Firms: Evidence from a Regression-Discontinuity Design. Review of Financial Studies 29, 3394-3427.

McCahery, Joseph A., Zacharias Sautner, and Laura T. Starks. 2016. Behind the Scenes: The Corporate Governance Preferences of Institutional Investors. Journal of Finance 71, 29052932.

Mueller, Holger M., Paige P. Ouimet, and Elena Simintzi. 2017. Within-Firm Pay Inequality. Review of Financial Studies 30, 3605-3635.

Murphy, Kevin J. 2013. Executive Compensation: Where We Are, and How We Got There. In Handbook of the Economics of Finance, Volume 2, edited by George M. Constantinides, Milton Harris, and René M. Stulz, 211-356. New York and Oxford: Elsevier/North-Holland.

Oyer, Paul. 2004. Why Do Firms Use Incentives That Have No Incentive Effects? Journal of Finance 59, 1619-1650.

Stein, Jeremy C. 1988. Takeover Threats and Managerial Myopia. Journal of Political Economy 46, 61-80.

Terviö, Marko. 2008. The Difference that CEOs Make: An Assignment Model Approach. American Economic Review 98, 642-668.

Zwiebel, Jeffrey. 1995. Corporate Conservatism and Relative Compensation. Journal of Political Economy 103, 1-25. 


\section{Table 1}

\section{Demographics of non-executive directors}

\begin{tabular}{|c|c|c|}
\hline \multicolumn{3}{|l|}{ Panel A: What size is your firm? } \\
\hline & $\%$ & $\mathrm{~N}$ \\
\hline FTSE 100 & $39 \%$ & 80 \\
\hline FTSE 250 & $35 \%$ & 72 \\
\hline FTSE Small Cap & $22 \%$ & 44 \\
\hline Don't know & $3 \%$ & 7 \\
\hline Total & $100 \%$ & 203 \\
\hline \multicolumn{3}{|l|}{ Panel B: What sector is your firm in? } \\
\hline & $\%$ & $\mathrm{~N}$ \\
\hline Retail/Wholesale & $10 \%$ & 21 \\
\hline Mining/Construction & $7 \%$ & 15 \\
\hline Manufacturing & $10 \%$ & 21 \\
\hline Transportation/Energy & $8 \%$ & 17 \\
\hline Communication/Media & $3 \%$ & 6 \\
\hline Banking/Finance/Insurance & $24 \%$ & 49 \\
\hline Tech (Hardware/Software) & $8 \%$ & 16 \\
\hline Service/Consulting & $4 \%$ & 8 \\
\hline Healthcare/Pharmaceutical/Biotech & $4 \%$ & 9 \\
\hline Property/Real Estate & $4 \%$ & 9 \\
\hline Other & $16 \%$ & 32 \\
\hline Total & $100 \%$ & 203 \\
\hline \multicolumn{3}{|c|}{ Panel C: What best describes your role at the firm? } \\
\hline & $\%$ & $\mathrm{~N}$ \\
\hline Chair & $27 \%$ & 55 \\
\hline Remuneration Committee Chair & $33 \%$ & 67 \\
\hline Remuneration Committee Member & $24 \%$ & 49 \\
\hline Other Non-Executive Director & $16 \%$ & 32 \\
\hline Total & $100 \%$ & 203 \\
\hline \multicolumn{3}{|c|}{ Panel D: What stake does your largest shareholder have? } \\
\hline & $\%$ & $\mathrm{~N}$ \\
\hline$>25 \%$ & $18 \%$ & 36 \\
\hline $10-25 \%$ & $27 \%$ & 55 \\
\hline $5-10 \%$ & $40 \%$ & 82 \\
\hline$<5 \%$ & $14 \%$ & 29 \\
\hline Don't know & $1 \%$ & 1 \\
\hline Total & $100 \%$ & 203 \\
\hline
\end{tabular}


Table 2

\section{Demographics of investors}

\begin{tabular}{|c|c|c|}
\hline \multicolumn{3}{|c|}{ Panel A: What type of institutional investor are you? } \\
\hline & $\%$ & $\mathrm{~N}$ \\
\hline Asset manager & $80 \%$ & 127 \\
\hline Asset owner & $8 \%$ & 12 \\
\hline Both & $13 \%$ & 20 \\
\hline Total & $100 \%$ & 159 \\
\hline \multicolumn{3}{|c|}{ Panel B: What best describes your role? } \\
\hline & $\%$ & $\mathrm{~N}$ \\
\hline $\begin{array}{l}\text { Governance, stewardship or } \\
\text { responsible investment }\end{array}$ & $52 \%$ & 82 \\
\hline Stock analyst & $8 \%$ & 13 \\
\hline Fund manager & $26 \%$ & 42 \\
\hline Chief investment officer & $6 \%$ & 9 \\
\hline Other & $8 \%$ & 13 \\
\hline Total & $100 \%$ & 159 \\
\hline \multicolumn{3}{|c|}{ Panel C: What is your investment style? } \\
\hline & $\%$ & $\mathrm{~N}$ \\
\hline Wholly index & $1 \%$ & 1 \\
\hline Mainly index & $4 \%$ & 6 \\
\hline Mainly active & $28 \%$ & 45 \\
\hline Wholly active & $61 \%$ & 97 \\
\hline Other & $6 \%$ & 10 \\
\hline Total & $100 \%$ & 159 \\
\hline \multicolumn{3}{|c|}{$\begin{array}{l}\text { Panel D: How large are your global equity assets under } \\
\text { management? }\end{array}$} \\
\hline & $\%$ & $\mathrm{~N}$ \\
\hline More than $£ 100 \mathrm{~b}$ & $47 \%$ & 75 \\
\hline Between $£ 50 \mathrm{~b}$ and $£ 100 \mathrm{~b}$ & $8 \%$ & 13 \\
\hline Between $£ 10 \mathrm{~b}$ and $£ 50 \mathrm{~b}$ & $20 \%$ & 31 \\
\hline Less than $£ 10 \mathrm{~b}$ & $25 \%$ & 40 \\
\hline Total & $100 \%$ & 159 \\
\hline
\end{tabular}


Table 3

Q1: Rank the importance of the following goals when setting CEO pay, by dragging the options below $(1=$ most important, $3=$ =east important $)$

The first row of responses for each option (not italicized) is from directors, the second row (italicized) is from investors.

\begin{tabular}{lccccc}
\hline & Mean & 1 & 2 & 3 & $\mathrm{~N}$ \\
\hline Attract/retain the right CEO & 1.39 & $65 \%$ & $32 \%$ & $4 \%$ & 203 \\
& 1.64 & $44 \%$ & $48 \%$ & $8 \%$ & 159 \\
Design a structure that motivates the & 1.70 & $34 \%$ & $61 \%$ & $5 \%$ & 203 \\
CEO & 1.56 & $51 \%$ & $42 \%$ & $7 \%$ & 159 \\
Keep the quantum of pay down & 2.90 & $1 \%$ & $8 \%$ & $91 \%$ & 203 \\
& 2.80 & $5 \%$ & $10 \%$ & $85 \%$ & 159 \\
\hline
\end{tabular}

\section{Table 4}

Q2a: How large a sacrifice in shareholder value would you make to avoid controversy on CEO pay? (1=none, $2=$ small sacrifice, $3=$ moderate sacrifice, $4=$ large sacrifice)

Investors: How large a sacrifice in shareholder value would you tolerate firms making to avoid controversy on CEO pay?

Q2b: How important is it to avoid controversy with the following parties? $(-2=$ not at all important, $2=$ very important)

The first row of responses for each option (not italicized) is from directors, the second row (italicized) is from investors.

\begin{tabular}{|c|c|c|c|c|c|c|c|}
\hline \multicolumn{8}{|l|}{ Panel A } \\
\hline & & Mean & 1 & 2 & 3 & 4 & $\mathrm{~N}$ \\
\hline \multicolumn{2}{|c|}{$\begin{array}{l}\text { value would you make to avoid } \\
\text { controversy on CEO pay? } \\
\text { How large a sacrifice in shareholder }\end{array}$} & 1.92 & $33 \%$ & $44 \%$ & $20 \%$ & $3 \%$ & 197 \\
\hline \multicolumn{2}{|c|}{$\begin{array}{l}\text { value would you tolerate firms making } \\
\text { to avoid controversy on CEO pay? }\end{array}$} & 1.74 & $44 \%$ & $40 \%$ & $13 \%$ & $3 \%$ & 153 \\
\hline \multicolumn{8}{|c|}{ Panel B } \\
\hline \multicolumn{2}{|c|}{ Mean } & -2 & -1 & 0 & 1 & 2 & $\mathrm{~N}$ \\
\hline Investors & $1.24^{\mathrm{a}, \mathrm{a}}$ & $0 \%$ & $2 \%$ & $9 \%$ & $50 \%$ & $38 \%$ & 128 \\
\hline Other investors & $0.24^{c, a}$ & $6 \%$ & $23 \%$ & $27 \%$ & $30 \%$ & $14 \%$ & 84 \\
\hline \multirow[t]{2}{*}{ Employees } & $0.69^{\mathrm{a}, \mathrm{a}}$ & $4 \%$ & $7 \%$ & $27 \%$ & $41 \%$ & $21 \%$ & 128 \\
\hline & $1.26^{a, a}$ & $0 \%$ & $6 \%$ & $12 \%$ & $32 \%$ & $50 \%$ & 84 \\
\hline \multirow[t]{2}{*}{ Proxy advisors } & $0.45^{\mathrm{a}, \mathrm{a}}$ & $2 \%$ & $12 \%$ & $38 \%$ & $34 \%$ & $13 \%$ & 128 \\
\hline & $-0.12_{-}^{-} a$ & $10 \%$ & $32 \%$ & $29 \%$ & $20 \%$ & $10 \%$ & 84 \\
\hline \multirow[t]{2}{*}{ Customers } & $0.20^{\mathrm{c}, \mathrm{a}}$ & $9 \%$ & $25 \%$ & $22 \%$ & $24 \%$ & $20 \%$ & 128 \\
\hline & $1.14^{a, a}$ & $1 \%$ & $7 \%$ & $17 \%$ & $26 \%$ & $49 \%$ & 84 \\
\hline \multirow[t]{2}{*}{ Policymakers } & $0.00_{-}^{-a}$ & $5 \%$ & $30 \%$ & $32 \%$ & $23 \%$ & $9 \%$ & 128 \\
\hline & $0.92^{a, a}$ & $2 \%$ & $5 \%$ & $27 \%$ & $30 \%$ & $36 \%$ & 84 \\
\hline \multirow[t]{2}{*}{ Media } & $-0.05-$ & $6 \%$ & $27 \%$ & $37 \%$ & $23 \%$ & $5 \%$ & 128 \\
\hline & $0.17^{-}-$ & $8 \%$ & $21 \%$ & $27 \%$ & $31 \%$ & $12 \%$ & 84 \\
\hline
\end{tabular}

The first superscript after the mean score reports whether it is significantly different from zero, the second superscript whether the means are significantly different for directors and investors. $a, b$, and c stand for statistically significant at the $1 \%, 5 \%$, and $10 \%$ level, respectively. 


\section{Table 5}

Q12a: Have any of the following ever caused you to offer a lower quantum of CEO pay than you would like? (Y/N)

\section{Q12b: Did this lower quantum ever lead to the following consequences?}

\begin{tabular}{lccc}
\hline Panel A & & & \\
\hline & Yes & No & N \\
\hline Risk of investor opposition & $60 \%$ & $40 \%$ & 172 \\
Risk of "vote against" recommendation from a proxy advisor & $53 \%$ & $47 \%$ & 172 \\
Restrictions from our existing approved pay policy & $44 \%$ & $56 \%$ & 172 \\
$\begin{array}{l}\text { Risk of controversy with employees, the media, customers, or } \\
\text { policymakers }\end{array}$ & $37 \%$ & $63 \%$ & 172 \\
Unwillingness to deviate substantially from how we have & $28 \%$ & $72 \%$ & 172 \\
paid in the past & & & \\
\hline Panel B & Yes & No & $\mathrm{N}$ \\
\hline & $42 \%$ & $58 \%$ & 132 \\
\hline The CEO was less motivated & $41 \%$ & $59 \%$ & 132 \\
There were no adverse consequences & $13 \%$ & $87 \%$ & 132 \\
We hire a less expensive CEO & $7 \%$ & $93 \%$ & 132 \\
The CEO left & & & \\
\hline
\end{tabular}

Table 6

Q13a: Have any of the following ever caused you to offer an inferior structure of CEO pay to what you would like? (Y/N)

Q13b: Was the structure inferior in the following ways?

\begin{tabular}{lccc}
\hline Panel A & & & \\
\hline & Yes & No & $\mathrm{N}$ \\
\hline Risk of "vote against" recommendation from a proxy advisor & $54 \%$ & $46 \%$ & 170 \\
Risk of investor opposition & $54 \%$ & $46 \%$ & 170 \\
Restrictions from our approved pay policy & $40 \%$ & $60 \%$ & 170 \\
Restrictions from regulation or governance codes & $36 \%$ & $64 \%$ & 170 \\
Risk of controversy with employees, the media, customers, or & $29 \%$ & $71 \%$ & 170 \\
policymakers & & & \\
Unwillingness to deviate substantially from how we have paid & $16 \%$ & $84 \%$ & 170 \\
in the past & $10 \%$ & $90 \%$ & 170 \\
Adverse tax, accounting, or disclosure implications & & & \\
\hline Panel B & Yes & No & $\mathrm{N}$ \\
\hline & $69 \%$ & $31 \%$ & 123 \\
\hline We followed market practice more & $65 \%$ & $35 \%$ & 123 \\
We offered less upside for good performance & $57 \%$ & $43 \%$ & 123 \\
We used (more) performance conditions & $40 \%$ & $60 \%$ & 123 \\
We made incentives more long-term & $13 \%$ & $87 \%$ & 123 \\
We made incentives more short-term & & \\
\hline
\end{tabular}




\section{Table 7}

\section{Q3: How important are the following factors in determining the target quantum of pay for a new CEO? (-2=not at all important, $2=$ very important)}

The first row of responses for each option (not italicized) is from directors, the second row (italicized) is from investors.

\begin{tabular}{|c|c|c|c|c|c|c|c|}
\hline & Mean & -2 & -1 & 0 & 1 & 2 & $\mathrm{~N}$ \\
\hline \multirow[t]{2}{*}{ The new CEO's ability } & $1.29^{\mathrm{a}, \mathrm{b}}$ & $4 \%$ & $2 \%$ & $9 \%$ & $31 \%$ & $54 \%$ & 188 \\
\hline & $1.49^{a, b}$ & $0 \%$ & $3 \%$ & $7 \%$ & $27 \%$ & $63 \%$ & 145 \\
\hline \multirow[t]{2}{*}{ CEO pay at peer firms } & $0.82^{\mathrm{a}, \mathrm{a}}$ & $1 \%$ & $8 \%$ & $24 \%$ & $41 \%$ & $26 \%$ & 188 \\
\hline & $0.46^{a, a}$ & $5 \%$ & $9 \%$ & $37 \%$ & $33 \%$ & $16 \%$ & 145 \\
\hline $\begin{array}{l}\text { How attractive our firm is to run (e.g. } \\
\text { prestige, risk, complexity) }\end{array}$ & $0.76^{\mathrm{a},-}$ & $4 \%$ & $7 \%$ & $22 \%$ & $45 \%$ & $22 \%$ & 188 \\
\hline $\begin{array}{l}\text { How attractive the firm is to run (e.g. } \\
\text { prestige, risk, complexity) }\end{array}$ & $0.61^{a_{-}}$ & $3 \%$ & $10 \%$ & $26 \%$ & $43 \%$ & $17 \%$ & 145 \\
\hline The new CEO's other employment & $0.55^{\mathrm{a}, \mathrm{b}}$ & $6 \%$ & $11 \%$ & $26 \%$ & $38 \%$ & $20 \%$ & 188 \\
\hline options & $0.26^{a, b}$ & $6 \%$ & $16 \%$ & $34 \%$ & $32 \%$ & $11 \%$ & 145 \\
\hline The new CEO's pay in their previous & $0.26^{\mathrm{a}, \mathrm{a}}$ & $5 \%$ & $15 \%$ & $38 \%$ & $32 \%$ & $9 \%$ & 188 \\
\hline position & $-0.21^{a, a}$ & $10 \%$ & $26 \%$ & $41 \%$ & $20 \%$ & $3 \%$ & 145 \\
\hline How financially motivated the new & $0.07-\mathrm{b}$ & $9 \%$ & $20 \%$ & $35 \%$ & $30 \%$ & $7 \%$ & 188 \\
\hline $\mathrm{CEO}$ is & $-0.23^{b, b}$ & $14 \%$ & $23 \%$ & $39 \%$ & $19 \%$ & $5 \%$ & 145 \\
\hline \multirow[t]{2}{*}{ The outgoing CEO's pay } & $-0.02 \_\mathrm{a}$ & $7 \%$ & $26 \%$ & $35 \%$ & $28 \%$ & $5 \%$ & 188 \\
\hline & $-0.55^{a, a}$ & $18 \%$ & $37 \%$ & $30 \%$ & $11 \%$ & $4 \%$ & 145 \\
\hline
\end{tabular}

The first superscript after the mean score reports whether it is significantly different from zero, the second superscript whether the means are significantly different for directors and investors. a, b, and c stand for statistically significant at the $1 \%, 5 \%$, and $10 \%$ level, respectively. 


\section{Table 8}

\section{Q4: What causes you to increase the target quantum of pay for an incumbent CEO? $(-2=$ strongly disagree, $2=$ strongly agree $)$ \\ Investors: What causes you to support increases to the target quantum of pay for an incumbent CEO?}

The first row of responses for each option (not italicized) is from directors, the second row (italicized) is from investors.

\begin{tabular}{|c|c|c|c|c|c|c|c|}
\hline & Mean & -2 & -1 & 0 & 1 & 2 & $\mathrm{~N}$ \\
\hline \multirow{2}{*}{ Good recent CEO performance } & $0.98^{\mathrm{a}_{2}}$ & $3 \%$ & $7 \%$ & $15 \%$ & $41 \%$ & $34 \%$ & 186 \\
\hline & $1.05^{a,-}$ & $0 \%$ & $5 \%$ & $20 \%$ & $41 \%$ & $35 \%$ & 142 \\
\hline \multirow[t]{2}{*}{ Increase in firm size } & $0.37^{\mathrm{a}, \mathrm{c}}$ & $4 \%$ & $15 \%$ & $35 \%$ & $33 \%$ & $13 \%$ & 186 \\
\hline & $0.17^{c, c}$ & $9 \%$ & $15 \%$ & $30 \%$ & $39 \%$ & $6 \%$ & 142 \\
\hline \multirow[t]{2}{*}{ Increase in pay at peer firms } & $0.26^{\mathrm{a}, \mathrm{a}}$ & $3 \%$ & $16 \%$ & $37 \%$ & $38 \%$ & $5 \%$ & 186 \\
\hline & $-0.17^{b, a}$ & $13 \%$ & $20 \%$ & $40 \%$ & $25 \%$ & $2 \%$ & 142 \\
\hline \multirow[t]{2}{*}{ Increased threat of CEO leaving } & $0.25^{\mathrm{a}, \mathrm{a}}$ & $5 \%$ & $17 \%$ & $35 \%$ & $35 \%$ & $8 \%$ & 186 \\
\hline & $-0.06 \overbrace{}^{a}$ & $8 \%$ & $24 \%$ & $38 \%$ & $27 \%$ & $3 \%$ & 142 \\
\hline $\begin{array}{l}\text { Changes in attractiveness (e.g. } \\
\text { prestige, risk, complexity) of CEO job } \\
\text { at your firm }\end{array}$ & $0.23^{\mathrm{a},}$ & $6 \%$ & $17 \%$ & $33 \%$ & $34 \%$ & $9 \%$ & 186 \\
\hline $\begin{array}{l}\text { Changes in attractiveness (e.g. } \\
\text { prestige, risk, complexity) of CEO job } \\
\text { at their firm }\end{array}$ & $0.25^{a,}$ & $8 \%$ & $13 \%$ & $34 \%$ & $36 \%$ & $9 \%$ & 142 \\
\hline Other changes that reduce the & $-0.11-$ & $8 \%$ & $26 \%$ & $38 \%$ & $25 \%$ & $3 \%$ & 186 \\
\hline adding holding periods) & $0.01-$ & $7 \%$ & $23 \%$ & $40 \%$ & $21 \%$ & $8 \%$ & 142 \\
\hline Changes in attractiveness (e.g. & $-0.28^{a,}$ & $10 \%$ & $30 \%$ & $41 \%$ & $16 \%$ & $3 \%$ & 186 \\
\hline jobs at other firms & $-0.37^{a,-}$ & $10 \%$ & $34 \%$ & $40 \%$ & $15 \%$ & $1 \%$ & 142 \\
\hline
\end{tabular}

The first superscript after the mean score reports whether it is significantly different from zero, the second superscript whether the means are significantly different for directors and investors. a, b, and c stand for statistically significant at the $1 \%, 5 \%$, and $10 \%$ level, respectively. 


\section{Table 9}

Q5a: Have you ever significantly decreased the target quantum of pay for an incumbent CEO? Investors: Have you ever requested significant decreases to the target quantum of pay for an incumbent CEO?

\section{Q5b: What caused you to decrease the target quantum of pay for an incumbent CEO? (-2=strongly disagree, $2=$ strongly agree) \\ Investors: What caused you to request decreases to the target quantum of pay for an incumbent CEO?}

The first row of responses for each option (not italicized) is from directors, the second row (italicized) is from investors.

\begin{tabular}{|c|c|c|c|c|c|c|c|}
\hline \multicolumn{8}{|l|}{ Panel A } \\
\hline & & & & & Yes & No & $\mathrm{N}$ \\
\hline \multicolumn{5}{|c|}{$\begin{array}{l}\text { Have you ever significantly decreased the target quantum of pay for an incumbent } \\
\text { CEO? }\end{array}$} & $23 \%$ & $77 \%$ & 186 \\
\hline \multicolumn{5}{|c|}{$\begin{array}{l}\text { Have you ever requested significant decreases to the target quantum of pay for an } \\
\text { incumbent CEO? }\end{array}$} & $65 \%$ & $35 \%$ & 142 \\
\hline \multicolumn{8}{|c|}{ Panel B } \\
\hline & Mean & -2 & -1 & 0 & 1 & 2 & $\mathrm{~N}$ \\
\hline \multirow{2}{*}{$\begin{array}{l}\text { External pressure to reduce pay (e.g. } \\
\text { from investors, the media, } \\
\text { policymakers) }\end{array}$} & 0.15 -c $^{\mathrm{c}}$ & $20 \%$ & $10 \%$ & $24 \%$ & $29 \%$ & $17 \%$ & 41 \\
\hline & $-0.28^{b, c}$ & $19 \%$ & $20 \%$ & $33 \%$ & $23 \%$ & $4 \%$ & 93 \\
\hline $\begin{array}{l}\text { Your firm encountering financial } \\
\text { constraints }\end{array}$ & $0.07-{ }_{-}$ & $32 \%$ & $12 \%$ & $5 \%$ & $20 \%$ & $32 \%$ & 41 \\
\hline $\begin{array}{l}\text { The firm encountering financial } \\
\text { constraints }\end{array}$ & $0.53^{a_{-}}$ & $13 \%$ & $9 \%$ & $20 \%$ & $29 \%$ & $29 \%$ & 93 \\
\hline \multirow{3}{*}{$\begin{array}{l}\text { The CEO requesting it* } \\
\text { Poor recent CEO performance }\end{array}$} & -0.37 & $49 \%$ & $0 \%$ & $10 \%$ & $22 \%$ & $20 \%$ & 41 \\
\hline & $-0.41 \perp^{\mathrm{a}}$ & $41 \%$ & $10 \%$ & $15 \%$ & $17 \%$ & $17 \%$ & 41 \\
\hline & $0.96^{a, a}$ & $6 \%$ & $6 \%$ & $17 \%$ & $25 \%$ & $45 \%$ & 93 \\
\hline \multirow[t]{2}{*}{ Decrease in firm size } & $-0.90^{a, b}$ & $46 \%$ & $20 \%$ & $17 \%$ & $12 \%$ & $5 \%$ & 41 \\
\hline & $-0.31^{b, b}$ & $23 \%$ & $18 \%$ & $35 \%$ & $15 \%$ & $9 \%$ & 93 \\
\hline \multirow[t]{2}{*}{ Decrease in pay at peer firms } & $-1.15^{\mathrm{a}, \mathrm{c}}$ & $56 \%$ & $17 \%$ & $15 \%$ & $10 \%$ & $2 \%$ & 41 \\
\hline & $-0.74^{a, c}$ & $29 \%$ & $28 \%$ & $32 \%$ & $10 \%$ & $1 \%$ & 93 \\
\hline $\begin{array}{l}\text { Change in attractiveness (e.g. prestige, } \\
\text { risk, complexity) of CEO job at your } \\
\text { firm }\end{array}$ & $-1.20^{\mathrm{a}, \mathrm{a}}$ & $56 \%$ & $17 \%$ & $17 \%$ & $10 \%$ & $0 \%$ & 41 \\
\hline $\begin{array}{l}\text { Change in attractiveness (e.g. } \\
\text { prestige, risk, complexity) of CEO job } \\
\text { at their firm }\end{array}$ & $-0.51^{a, a}$ & $22 \%$ & $28 \%$ & $34 \%$ & $12 \%$ & $4 \%$ & 93 \\
\hline \multirow{2}{*}{$\begin{array}{l}\text { Change in attractiveness (e.g. prestige, } \\
\text { risk, complexity) of CEO jobs at other } \\
\text { firms }\end{array}$} & $-1.41^{\mathrm{a}, \mathrm{a}}$ & $63 \%$ & $20 \%$ & $12 \%$ & $5 \%$ & $0 \%$ & 41 \\
\hline & $-0.80^{a, a}$ & $28 \%$ & $35 \%$ & $28 \%$ & $5 \%$ & $3 \%$ & 93 \\
\hline
\end{tabular}

The first superscript after the mean score reports whether it is significantly different from zero, the second superscript whether the means are significantly different for directors and investors. a, b, and c stand for statistically significant at the $1 \%, 5 \%$, and $10 \%$ level, respectively. ${ }^{*}$ Only directors were asked this question. 


\section{Table 10}

Q6: If your firm reduced the target quantum pay of its next CEO by $1 / 3$ compared to its current CEO, what might happen? (-2=very unlikely outcome, $2=$ very likely outcome)

Investors: If a firm reduced the target quantum pay of its next CEO by 1/3 compared to its current CEO, what might happen?

The first row of responses for each option (not italicized) is from directors, the second row (italicized) is from investors.

\begin{tabular}{lccccccc}
\hline & Mean & -2 & -1 & 0 & 1 & 2 & $\mathrm{~N}$ \\
\hline We would recruit a lower quality CEO & $0.66^{\mathrm{a}, \mathrm{a}}$ & $7 \%$ & $9 \%$ & $25 \%$ & $30 \%$ & $29 \%$ & 182 \\
The firm would recruit a lower quality CEO & $-0.32^{a, a}$ & $11 \%$ & $30 \%$ & $41 \%$ & $15 \%$ & $3 \%$ & 140 \\
The CEO would be less motivated & $0.38^{\mathrm{a}, \mathrm{a}}$ & $4 \%$ & $19 \%$ & $31 \%$ & $26 \%$ & $20 \%$ & 182 \\
& $-0.31^{a, a}$ & $15 \%$ & $27 \%$ & $34 \%$ & $21 \%$ & $2 \%$ & 140 \\
$\begin{array}{l}\text { It would create undesirable pay } \\
\text { compression between the CEO and other }\end{array}$ & $0.36^{\mathrm{a}, \mathrm{a}}$ & $7 \%$ & $16 \%$ & $26 \%$ & $37 \%$ & $14 \%$ & 182 \\
executives & $-0.50^{a, a}$ & $16 \%$ & $36 \%$ & $31 \%$ & $14 \%$ & $2 \%$ & 140 \\
$\begin{array}{l}\text { We would have a strained relationship with } \\
\text { the CEO }\end{array}$ & $0.32^{\mathrm{a}, \mathrm{a}}$ & $7 \%$ & $19 \%$ & $29 \%$ & $26 \%$ & $19 \%$ & 182 \\
$\begin{array}{l}\text { The board would have a strained } \\
\text { relationship with the CEO }\end{array}$ & $-0.48^{a, a}$ & $14 \%$ & $34 \%$ & $39 \%$ & $9 \%$ & $3 \%$ & 140 \\
$\begin{array}{l}\text { It would send a negative signal about CEO } \\
\text { quality to the market }\end{array}$ & $0.29^{\mathrm{a}, \mathrm{a}}$ & $8 \%$ & $19 \%$ & $24 \%$ & $36 \%$ & $14 \%$ & 182 \\
& $-0.36^{a, a}$ & $14 \%$ & $33 \%$ & $32 \%$ & $16 \%$ & $5 \%$ & 140 \\
There would be no adverse consequences & $-0.96^{\mathrm{a}, \mathrm{a}}$ & $41 \%$ & $26 \%$ & $23 \%$ & $7 \%$ & $3 \%$ & 182 \\
& $-0.02-^{a}$ & $9 \%$ & $23 \%$ & $35 \%$ & $26 \%$ & $6 \%$ & 140 \\
\hline
\end{tabular}

The first superscript after the mean score reports whether it is significantly different from zero, the second superscript whether the means are significantly different for directors and investors. $\mathrm{a}, \mathrm{b}$, and c stand for statistically significant at the $1 \%, 5 \%$, and $10 \%$ level, respectively.

\section{Table 11}

Q15a: Do you believe the overall level of CEO pay is too low, too high, or about right? $(-2=$ far too low, $0=$ about right, $2=$ far too high)

Q15b: How strongly do you agree with the following statements for why the overall level of CEO pay is so high? (-2=strongly disagree, $2=$ strongly agree)

\begin{tabular}{|c|c|c|c|c|c|c|c|}
\hline Panel A & & & & & & & \\
\hline & Mean & -2 & -1 & 0 & 1 & 2 & $\mathrm{~N}$ \\
\hline $\begin{array}{l}\text { Do you believe the overall level of CEO } \\
\text { pay is too low, too high, or about right? }\end{array}$ & $0.95^{\mathrm{a}}$ & $0 \%$ & $4 \%$ & $20 \%$ & $55 \%$ & $22 \%$ & 132 \\
\hline Panel B & & & & & & & \\
\hline & Mean & -2 & -1 & 0 & 1 & 2 & $\mathrm{~N}$ \\
\hline $\begin{array}{l}\text { Boards are ineffective at lowering it } \\
\text { even though they should }\end{array}$ & $1.22^{\mathrm{a}}$ & $1 \%$ & $2 \%$ & $11 \%$ & $47 \%$ & $40 \%$ & 101 \\
\hline $\begin{array}{l}\text { Investors have insufficient power over } \\
\text { boards to lower it }\end{array}$ & $0.48^{\mathrm{a}}$ & $6 \%$ & $16 \%$ & $22 \%$ & $38 \%$ & $19 \%$ & 101 \\
\hline $\begin{array}{l}\text { Investors focus their engagement on } \\
\text { more important topics than the level of } \\
\text { pay }\end{array}$ & -0.07 & $9 \%$ & $39 \%$ & $17 \%$ & $22 \%$ & $14 \%$ & 101 \\
\hline
\end{tabular}

The superscript after the mean score reports whether it is significantly different from zero. a, b, and c stand for statistically significant at the $1 \%, 5 \%$, and $10 \%$ level, respectively. 


\section{Table 12}

\section{Q7: What motivates your CEO to perform strongly? $(-2=$ not at all important, $2=$ very important) \\ Investors: What motivates CEOs to perform strongly?}

The first row of responses for each option (not italicized) is from directors, the second row (italicized) is from investors.

\begin{tabular}{|c|c|c|c|c|c|c|c|}
\hline & Mean & -2 & -1 & 0 & 1 & 2 & $\mathrm{~N}$ \\
\hline \multirow[t]{2}{*}{ Intrinsic motivation } & $1.55^{\mathrm{a},}$ & $2 \%$ & $1 \%$ & $4 \%$ & $24 \%$ & $68 \%$ & 181 \\
\hline & $1.50^{a,}$ & $0 \%$ & $1 \%$ & $9 \%$ & $31 \%$ & $60 \%$ & 139 \\
\hline \multirow[t]{2}{*}{ Personal reputation } & $1.40^{\mathrm{a}, \mathrm{b}}$ & $3 \%$ & $1 \%$ & $6 \%$ & $36 \%$ & $55 \%$ & 181 \\
\hline & $1.60^{a, b}$ & $0 \%$ & $0 \%$ & $4 \%$ & $33 \%$ & $63 \%$ & 139 \\
\hline \multirow{4}{*}{$\begin{array}{l}\text { Incentives from bonuses, LTIPs, } \\
\text { equity, or future pay increases } \\
\text { Industry competition }\end{array}$} & $0.98^{\mathrm{a},}$ & $2 \%$ & $6 \%$ & $17 \%$ & $46 \%$ & $30 \%$ & 181 \\
\hline & $0.83^{a,}$ & $1 \%$ & $8 \%$ & $24 \%$ & $42 \%$ & $25 \%$ & 139 \\
\hline & $0.62^{\mathrm{a}, \mathrm{c}}$ & $2 \%$ & $13 \%$ & $24 \%$ & $44 \%$ & $18 \%$ & 181 \\
\hline & $0.82^{a, c}$ & $1 \%$ & $6 \%$ & $26 \%$ & $44 \%$ & $23 \%$ & 139 \\
\hline \multirow[t]{2}{*}{ The quantum of pay } & $0.55^{\mathrm{a}, \mathrm{a}}$ & $2 \%$ & $12 \%$ & $31 \%$ & $40 \%$ & $15 \%$ & 181 \\
\hline & $0.21^{a, a}$ & $3 \%$ & $17 \%$ & $42 \%$ & $31 \%$ & $6 \%$ & 139 \\
\hline \multirow[t]{2}{*}{ The potential to move to a bigger firm } & $-0.53^{\mathrm{a}, \mathrm{a}}$ & $19 \%$ & $35 \%$ & $29 \%$ & $16 \%$ & $2 \%$ & 181 \\
\hline & $0.37^{a, a}$ & $4 \%$ & $13 \%$ & $37 \%$ & $35 \%$ & $12 \%$ & 139 \\
\hline \multirow[t]{2}{*}{ Risk of being fired } & $-0.88^{\mathrm{a}, \mathrm{a}}$ & $30 \%$ & $41 \%$ & $18 \%$ & $9 \%$ & $2 \%$ & 181 \\
\hline & $-0.20^{b, a}$ & $11 \%$ & $27 \%$ & $37 \%$ & $22 \%$ & $3 \%$ & 139 \\
\hline
\end{tabular}

The first superscript after the mean score reports whether it is significantly different from zero, the second superscript whether the means are significantly different for directors and investors. $\mathrm{a}, \mathrm{b}$, and c stand for statistically significant at the $1 \%, 5 \%$, and $10 \%$ level, respectively.

\section{Table 13}

\section{Q8: Why do you offer the CEO variable pay? (-2=strongly disagree, $2=$ strongly agree) Investors: Why should CEOs be offered variable pay?}

The first row of responses for each option (not italicized) is from directors, the second row (italicized) is from investors.

\begin{tabular}{|c|c|c|c|c|c|c|c|}
\hline & Mean & -2 & -1 & 0 & 1 & 2 & $\mathrm{~N}$ \\
\hline \multirow[t]{2}{*}{$\begin{array}{l}\text { To motivate the CEO to improve long- } \\
\text { term shareholder value }\end{array}$} & $1.46^{\mathrm{a},-}$ & $2 \%$ & $2 \%$ & $7 \%$ & $26 \%$ & $63 \%$ & 179 \\
\hline & $1.36^{a,-}$ & $1 \%$ & $4 \%$ & $8 \%$ & $31 \%$ & $55 \%$ & 137 \\
\hline \multirow{4}{*}{$\begin{array}{l}\text { To attract/retain a high-ability or hard- } \\
\text { working CEO } \\
\text { So that the CEO shares risks with } \\
\text { investors and stakeholders, even if out } \\
\text { of the CEO's control }\end{array}$} & $1.19^{\mathrm{a}, \mathrm{a}}$ & $2 \%$ & $2 \%$ & $8 \%$ & $49 \%$ & $39 \%$ & 179 \\
\hline & $0.85^{a, a}$ & $4 \%$ & $7 \%$ & $19 \%$ & $37 \%$ & $32 \%$ & 137 \\
\hline & $1.16^{\mathrm{a},-}$ & $3 \%$ & $2 \%$ & $10 \%$ & $44 \%$ & $41 \%$ & 179 \\
\hline & $1.14^{a_{-}}$ & $4 \%$ & $4 \%$ & $14 \%$ & $33 \%$ & $46 \%$ & 137 \\
\hline \multirow{3}{*}{$\begin{array}{l}\text { To motivate the CEO to improve } \\
\text { outcomes other than long-term } \\
\text { shareholder value } \\
\text { To match peer firm practice }\end{array}$} & $0.46^{\mathrm{a},-}$ & $9 \%$ & $13 \%$ & $26 \%$ & $27 \%$ & $25 \%$ & 179 \\
\hline & $0.47^{a,}$ & $10 \%$ & $13 \%$ & $23 \%$ & $26 \%$ & $27 \%$ & 137 \\
\hline & $\begin{array}{l}0.37^{\mathrm{a}, \mathrm{a}} \\
-0.45^{a, a}\end{array}$ & $\begin{array}{l}5 \% \\
15 \%\end{array}$ & $\begin{array}{l}14 \% \\
31 \%\end{array}$ & $\begin{array}{l}32 \% \\
39 \%\end{array}$ & $\begin{array}{l}36 \% \\
12 \%\end{array}$ & $\begin{array}{c}12 \% \\
3 \%\end{array}$ & $\begin{array}{l}179 \\
137\end{array}$ \\
\hline $\begin{array}{l}\text { Because investors or proxy advisors } \\
\text { require it* }\end{array}$ & $-0.17^{c}$ & $18 \%$ & $20 \%$ & $31 \%$ & $23 \%$ & $8 \%$ & 179 \\
\hline $\begin{array}{l}\text { So that the quantum of pay can be } \\
\text { justified }\end{array}$ & $\begin{array}{l}-0.42^{a{ }_{-}} \\
-0.34^{a,-}\end{array}$ & $\begin{array}{l}22 \% \\
23 \%\end{array}$ & $\begin{array}{l}30 \% \\
26 \%\end{array}$ & $\begin{array}{l}21 \% \\
26 \%\end{array}$ & $\begin{array}{l}21 \% \\
11 \% \\
\end{array}$ & $\begin{array}{l}6 \% \\
14 \% \\
\end{array}$ & $\begin{array}{l}179 \\
137\end{array}$ \\
\hline
\end{tabular}

The first superscript after the mean score reports whether it is significantly different from zero, the second superscript whether the means are significantly different for directors and investors. a, b, and c stand for statistically significant at the $1 \%, 5 \%$, and $10 \%$ level, respectively. ${ }^{*}$ Only directors were asked this question. 


\section{Table 14}

\section{Q9: What determines the split between fixed and variable pay? $(-2=$ not at all important, $2=$ very important) \\ Investors: What should determine the split between fixed and variable pay?}

The first row of responses for each option (not italicized) is from directors, the second row (italicized) is from investors.

\begin{tabular}{lccccccc}
\hline & Mean & -2 & -1 & 0 & 1 & 2 & $\mathrm{~N}$ \\
\hline How much the CEO can affect firm & $0.66^{\mathrm{a}, \mathrm{a}}$ & $7 \%$ & $9 \%$ & $21 \%$ & $35 \%$ & $27 \%$ & 178 \\
performance & $0.98^{a, a}$ & $1 \%$ & $5 \%$ & $19 \%$ & $44 \%$ & $31 \%$ & 135 \\
Investors or proxy advisor & $0.55^{\mathrm{a}}$ & $7 \%$ & $7 \%$ & $26 \%$ & $43 \%$ & $17 \%$ & 178 \\
expectations* & $0.37^{\mathrm{a}, \mathrm{a}}$ & $6 \%$ & $10 \%$ & $35 \%$ & $38 \%$ & $11 \%$ & 178 \\
The split between fixed and variable & $-0.49^{a, a}$ & $16 \%$ & $28 \%$ & $45 \%$ & $9 \%$ & $1 \%$ & 135 \\
pay in peer firms & $0.30^{\mathrm{a},-}$ & $8 \%$ & $13 \%$ & $29 \%$ & $37 \%$ & $12 \%$ & 178 \\
CEO intrinsic motivation & $0.12 a_{-}^{\mathrm{a}-}$ & $13 \%$ & $16 \%$ & $32 \%$ & $25 \%$ & $14 \%$ & 135 \\
& $0.24^{\mathrm{a}-}$ & $10 \%$ & $19 \%$ & $21 \%$ & $38 \%$ & $12 \%$ & 178 \\
The desire to avoid excessive pay & $0.30^{a,-}$ & $7 \%$ & $21 \%$ & $24 \%$ & $30 \%$ & $18 \%$ & 135 \\
outcomes & $-0.44^{\mathrm{a}, \mathrm{a}}$ & $17 \%$ & $29 \%$ & $38 \%$ & $12 \%$ & $3 \%$ & 178 \\
How risky our firm is & $0.29^{a, a}$ & $7 \%$ & $13 \%$ & $32 \%$ & $38 \%$ & $10 \%$ & 135 \\
& $-0.46^{\mathrm{a},-}$ & $20 \%$ & $31 \%$ & $27 \%$ & $19 \%$ & $3 \%$ & 178 \\
CEO personal risk appetite & $-0.45^{a_{-}}$ & $19 \%$ & $30 \%$ & $32 \%$ & $19 \%$ & $1 \%$ & 135 \\
\hline
\end{tabular}

The first superscript after the mean score reports whether it is significantly different from zero, the second superscript whether the means are significantly different for directors and investors. a, b, and c stand for statistically significant at the $1 \%, 5 \%$, and $10 \%$ level, respectively. ${ }^{*}$ Only directors were asked this question.

\section{Table 15}

\section{Q10: What would happen if you made the CEO's incentives more long-term? $(-2=$ very unlikely outcome, $2=$ very likely outcome) Investors: What would happen if companies made CEO incentives more long-term?}

The first row of responses for each option (not italicized) is from directors, the second row (italicized) is from investors.

\begin{tabular}{|c|c|c|c|c|c|c|c|}
\hline & Mean & -2 & -1 & 0 & 1 & 2 & $\mathrm{~N}$ \\
\hline The incentives would lose their & $0.20^{\mathrm{b}, \mathrm{a}}$ & $6 \%$ & $25 \%$ & $25 \%$ & $31 \%$ & $13 \%$ & 177 \\
\hline effectiveness & $-0.98^{a, a}$ & $30 \%$ & $44 \%$ & $21 \%$ & $4 \%$ & $1 \%$ & 135 \\
\hline $\begin{array}{l}\text { We would have to pay the CEO more, } \\
\text { which would outweigh any benefits }\end{array}$ & $0.14^{\mathrm{c}, \mathrm{a}}$ & $7 \%$ & $18 \%$ & $37 \%$ & $29 \%$ & $9 \%$ & 177 \\
\hline $\begin{array}{l}\text { The CEO would need to be paid more, } \\
\text { which would outweigh any benefits }\end{array}$ & $-0.81^{a, a}$ & $19 \%$ & $51 \%$ & $24 \%$ & $4 \%$ & $2 \%$ & 135 \\
\hline $\begin{array}{l}\text { We would be unable to attract/retain } \\
\text { the CEO we want }\end{array}$ & $0.13_{-}^{-\mathrm{a}}$ & $7 \%$ & $19 \%$ & $34 \%$ & $31 \%$ & $8 \%$ & 177 \\
\hline $\begin{array}{l}\text { The board would be unable to } \\
\text { attract/retain the CEO it wants }\end{array}$ & $-0.95^{a, a}$ & $28 \%$ & $45 \%$ & $21 \%$ & $4 \%$ & $1 \%$ & 135 \\
\hline The CEO would make better decisions & $\begin{array}{l}-0.40^{\mathrm{a}, \mathrm{a}} \\
1.14^{a, a}\end{array}$ & $\begin{array}{c}21 \% \\
1 \% \\
\end{array}$ & $\begin{array}{c}25 \% \\
4 \% \\
\end{array}$ & $\begin{array}{l}32 \% \\
16 \%\end{array}$ & $\begin{array}{l}15 \% \\
34 \% \\
\end{array}$ & $\begin{array}{l}7 \% \\
44 \% \\
\end{array}$ & $\begin{array}{l}177 \\
135\end{array}$ \\
\hline
\end{tabular}

The first superscript after the mean score reports whether it is significantly different from zero, the second superscript whether the means are significantly different for directors and investors. $a, b$, and c stand for statistically significant at the $1 \%, 5 \%$, and $10 \%$ level, respectively. 
Table 16

Q11a: Do you filter out industry conditions from all performance measures (e.g. by benchmarking against peers)?

Investors: Do you believe that industry conditions should be filtered out from all performance measures (e.g. by benchmarking against peers)?

\section{Q11b: Why don't you filter out industry conditions from all performance measures? (-2=strongly disagree, $2=$ strongly agree) \\ Investors: Why don't you believe that industry conditions should be filtered out from all performance measures?}

The first row of responses for each option (not italicized) is from directors, the second row (italicized) is from investors.

\begin{tabular}{|c|c|c|c|c|c|c|c|}
\hline \multicolumn{8}{|l|}{ Panel A } \\
\hline & & & & & Yes & No & $\mathrm{N}$ \\
\hline \multirow{2}{*}{\multicolumn{5}{|c|}{$\begin{array}{l}\text { Do you filter out industry conditions from all performance measures } \\
\text { Do you believe that industry conditions should be filtered out from all performance } \\
\text { measures? }\end{array}$}} & $37 \%$ & $63 \%$ & 175 \\
\hline & & & & & $25 \%$ & $75 \%$ & 135 \\
\hline \multicolumn{8}{|c|}{ Panel B } \\
\hline & Mean & -2 & -1 & 0 & 1 & 2 & $\mathrm{~N}$ \\
\hline $\begin{array}{l}\text { The CEO should benefit from an } \\
\text { industry upswing, since investors and } \\
\text { stakeholders do }\end{array}$ & $0.44^{\mathrm{a}, \mathrm{a}}$ & $2 \%$ & $9 \%$ & $46 \%$ & $29 \%$ & $14 \%$ & 107 \\
\hline $\begin{array}{l}\text { CEOs should benefit from an industry } \\
\text { upswing, since investors and } \\
\text { stakeholders do }\end{array}$ & $0.05\lrcorner^{a}$ & $8 \%$ & $19 \%$ & $40 \%$ & $24 \%$ & $8 \%$ & 98 \\
\hline It is too difficult to define an & $0.20-$ & $12 \%$ & $21 \%$ & $23 \%$ & $21 \%$ & $22 \%$ & 107 \\
\hline appropriate peer group & $-0.06--$ & $9 \%$ & $26 \%$ & $37 \%$ & $19 \%$ & $9 \%$ & 98 \\
\hline We don't have information on peer & $0.17--$ & $18 \%$ & $14 \%$ & $21 \%$ & $27 \%$ & $20 \%$ & 107 \\
\hline $\begin{array}{l}\text { The board doesn't have information } \\
\text { on peer performance for some } \\
\text { measures }\end{array}$ & $-0.12--$ & $14 \%$ & $26 \%$ & $27 \%$ & $26 \%$ & $8 \%$ & 98 \\
\hline $\begin{array}{l}\text { Investors don't want us to filter out } \\
\text { industry conditions* }\end{array}$ & 0.11 & $8 \%$ & $14 \%$ & $46 \%$ & $21 \%$ & $10 \%$ & 107 \\
\hline Benchmarking all performance & $-0.23^{\mathrm{b}, \mathrm{b}}$ & $12 \%$ & $29 \%$ & $32 \%$ & $24 \%$ & $3 \%$ & 107 \\
\hline mimicking peers & $0.14\lrcorner^{b}$ & $10 \%$ & $19 \%$ & $30 \%$ & $28 \%$ & $13 \%$ & 98 \\
\hline $\begin{array}{l}\text { Relative performance measures are } \\
\text { less motivating for the CEO }\end{array}$ & $-0.26^{\mathrm{a}_{-}}$ & $11 \%$ & $32 \%$ & $33 \%$ & $21 \%$ & $4 \%$ & 107 \\
\hline $\begin{array}{l}\text { Relative performance measures are } \\
\text { less motivating for } C E O S\end{array}$ & $-0.46^{a_{-}}$ & $18 \%$ & $36 \%$ & $24 \%$ & $16 \%$ & $5 \%$ & 98 \\
\hline $\begin{array}{l}\text { In an industry upswing, not } \\
\text { benchmarking performance keeps our } \\
\text { pay competitive with peers }\end{array}$ & $-0.32^{a_{-}}$ & $18 \%$ & $22 \%$ & $36 \%$ & $22 \%$ & $2 \%$ & 107 \\
\hline $\begin{array}{l}\text { In an industry upswing, not } \\
\text { benchmarking performance keeps the } \\
\text { pay competitive with peers }\end{array}$ & $-0.17^{c_{-}}$ & $10 \%$ & $21 \%$ & $47 \%$ & $18 \%$ & $3 \%$ & 98 \\
\hline $\begin{array}{l}\text { The CEO is responsible for choosing } \\
\text { what industries our firm operates in }\end{array}$ & $\begin{array}{l}-1.07^{\mathrm{a}, \mathrm{a}} \\
-0.42^{a, a}\end{array}$ & $\begin{array}{l}53 \% \\
18 \%\end{array}$ & $\begin{array}{l}21 \% \\
33 \%\end{array}$ & $\begin{array}{l}10 \% \\
29 \%\end{array}$ & $\begin{array}{l}8 \% \\
13 \%\end{array}$ & $\begin{array}{l}7 \% \\
7 \%\end{array}$ & $\begin{array}{r}107 \\
98\end{array}$ \\
\hline
\end{tabular}

The first superscript after the mean score reports whether it is significantly different from zero, the second superscript whether the means are significantly different for directors and investors. $\mathrm{a}, \mathrm{b}$, and c stand for statistically significant at the $1 \%, 5 \%$, and $10 \%$ level, respectively. ${ }^{*}$ Only directors were asked this question. 


\section{Table 17}

\section{Q16: How much influence do you believe investors have on CEO pay? $(-2=$ no influence, $2=$ high influence)}

\begin{tabular}{lccccccc}
\hline & Mean & -2 & -1 & 0 & 1 & 2 & $\mathrm{~N}$ \\
\hline $\begin{array}{l}\text { How much influence do you believe } \\
\text { investors have on CEO pay? }\end{array}$ & $0.21^{\mathrm{a}}$ & $2 \%$ & $18 \%$ & $40 \%$ & $35 \%$ & $5 \%$ & 132 \\
\hline
\end{tabular}

The superscript after the mean score reports whether it is significantly different from zero. $a, b$, and $\mathrm{c}$ stand for statistically significant at the $1 \%, 5 \%$, and $10 \%$ level, respectively.

\section{Table 18}

\section{Q14: How much do the following influence CEO pay compared to the optimal level? $(-2=$ much less than they should, $0=$ about right, $2=$ much more than they should)}

The first row of responses for each option (not italicized) is from directors, the second row (italicized) is from investors.

\begin{tabular}{|c|c|c|c|c|c|c|c|}
\hline & Mean & -2 & -1 & 0 & 1 & 2 & $\mathrm{~N}$ \\
\hline \multirow[t]{2}{*}{ Proxy advisors } & $1.00^{\mathrm{a}, \mathrm{a}}$ & $1 \%$ & $6 \%$ & $21 \%$ & $35 \%$ & $36 \%$ & 170 \\
\hline & $0.33^{a, a}$ & $1 \%$ & $17 \%$ & $39 \%$ & $34 \%$ & $9 \%$ & 132 \\
\hline \multirow[t]{2}{*}{ Investors } & $0.38^{\mathrm{a}, \mathrm{a}}$ & $2 \%$ & $4 \%$ & $57 \%$ & $29 \%$ & $8 \%$ & 170 \\
\hline & $-0.65^{a, a}$ & $11 \%$ & $51 \%$ & $30 \%$ & $7 \%$ & $1 \%$ & 132 \\
\hline \multirow[t]{2}{*}{ Pay consultants } & $0.32^{\mathrm{a}, \mathrm{a}}$ & $2 \%$ & $4 \%$ & $64 \%$ & $22 \%$ & $9 \%$ & 170 \\
\hline & $0.97^{a, a}$ & $2 \%$ & $4 \%$ & $23 \%$ & $36 \%$ & $35 \%$ & 132 \\
\hline \multirow[t]{2}{*}{$\mathrm{CEO}$} & $0.24^{\mathrm{a}, \mathrm{a}}$ & $1 \%$ & $4 \%$ & $68 \%$ & $24 \%$ & $3 \%$ & 170 \\
\hline & $0.80^{a, a}$ & $1 \%$ & $2 \%$ & $33 \%$ & $45 \%$ & $19 \%$ & 132 \\
\hline \multirow{2}{*}{$\begin{array}{l}\text { Employees, the media, customers, or } \\
\text { policymakers }\end{array}$} & $0.08-\mathrm{c}$ & $2 \%$ & $15 \%$ & $59 \%$ & $19 \%$ & $4 \%$ & 170 \\
\hline & $-0.11+c$ & $8 \%$ & $27 \%$ & $38 \%$ & $23 \%$ & $5 \%$ & 132 \\
\hline \multirow[t]{2}{*}{ Board } & $-0.06--$ & $4 \%$ & $9 \%$ & $76 \%$ & $8 \%$ & $2 \%$ & 170 \\
\hline & $-0.11--$ & $2 \%$ & $30 \%$ & $48 \%$ & $15 \%$ & $5 \%$ & 132 \\
\hline \multirow[t]{2}{*}{ HR director } & $-0.18^{a, b}$ & $6 \%$ & $12 \%$ & $76 \%$ & $5 \%$ & $1 \%$ & 170 \\
\hline & $0.04, b$ & $5 \%$ & $14 \%$ & $60 \%$ & $14 \%$ & $7 \%$ & 132 \\
\hline
\end{tabular}

The first superscript after the mean score reports whether it is significantly different from zero, the second superscript whether the means are significantly different for directors and investors. a, b, and c stand for statistically significant at the $1 \%, 5 \%$, and $10 \%$ level, respectively. 